Yayın Geliş Tarihi: 18.04.2020

Yayına Kabul Tarihi: 06.04.2021

Online Yayın Tarihi: 30.06.2021

http://dx.doi.org/10.16953/deusosbil.722869
Dokuz Eylül Üniversitesi

Sosyal Bilimler Enstitüsü Dergisi

Cilt: 23, Say1: 2, Y11: 2021, Sayfa: 869-900

ISSN: 1302-3284 E-ISSN: 1308-0911

Araştırma Makalesi

\title{
BANKACILIK SEKTÖRÜ ÇALIŞANLARININ SOSYAL TİCARETE İLGILERİ ÜZERINE BİR ARAŞTIRMA ${ }^{1}$
}

\author{
Murat Can AKTAŞ* \\ Ersin KARAMAN** \\ $\ddot{O} z$ \\ Mehmet Cem BÖLEN ${ }^{* *}$
}

Ticaret, insan hayatında uzun süredir var olan alanlardan biridir. Geçmişten günümüze iletişim ve teknoloji alanlarında yaşanan gelişmeler, ticaret için de farkl zeminler oluşmasını sağlamıştır. Sosyal medya platformları ile ticaret faaliyetlerinin kesiştiği noktada ortaya çıkan sosyal ticaret alanı için günümüzün gelişmekte olan yeni ticaret ortamlarından biri konumundadır. Bu çalışmada, bankacılık sektörü çalışanlarının sosyal ticaret üzerine ilgileri demografik özellikler üzerinden karşılaştırılarak incelenmektedir. Kullanıcılardan veri toplama aşamasında anket yöntemi tercih edilmiştir. Pilot çalışmada 81 banka personeli çalışmaya katılmıştır. Pilot çalışmanın ardından bankacılık sektörü çalışanlarına yönelik olarak 402 katılımcı anket formundaki ifadeleri yanıtlamıștır. Toplanan yanıtlar üzerinde faktör analizi yapılmış ve genel ilgi dışında beş farklı ilgi başlı̆̆ belirlenmiştir. Yapılan analizler sonucunda beş farklı ilgiye göre katılımcıların demografik özellikleri arasındaki farklılıklar incelenmiştir. Çalışma sonucunda; genç katılımcıların sosyal ticaret ilgilerinin diğer demografik özelliklerdeki katılımcılara göre daha yüksek olduğu sonucuna ulaşılmıştır. Ayrıca cinsiyet özelliği açısından yapılan karşılaştırmalarda kadın katılımcıların sosyal ticaret faaliyetlerine daha fazla ilgi gösterdikleri belirlenmiştir.

Anahtar Kelimeler: Sosyal ticaret, S-Ticaret, Sosyal Medya, E-Ticaret, Mobil Ticaret.

\footnotetext{
${ }^{1}$ Bu makale Doç. Dr. Ersin KARAMAN'ın danışmanlığında Murat Can AKTAŞ tarafından hazırlanan "Bankacılık Sektörü Çalışanlarının Sosyal Ticarete İlgileri Üzerine Bir Araştırma" adlı Yüksek Lisans tezinden üretilmiştir.

Bu makale için önerilen kaynak gösterimi (APA 6. Sürüm):

Aktaş, M. C., Karaman, E., Bölen, M. C., (2021). Bankacılık sektörü çalışanlarının sosyal ticarete ilgileri üzerine bir araştırma. Dokuz Eylül Üniversitesi Sosyal Bilimler Enstitüsü Dergisi, 23 (2), 869-900.

* Doktora Öğrencisi, Atatürk Üniversitesi, İktisadi ve İdari Bilimler Fakültesi, Yönetim Bilişim Sistemleri Bölümü, ORCID: 0000-0003-0517-335X, murataktas.net.tr@gmail.com.

** Doç. Dr., Ankara Hacı Bayram Veli Üniversitesi, İktisadi ve İdari Bilimler Fakültesi, Yönetim Bilişim Sistemleri Bölümü, ORCID: 0000-0002-6075-2779, ersin.karaman @ hbv.edu.tr.

** Dr. Öğr. Üyesi, Atatürk Üniversitesi, Açıköğretim Fakültesi, İşletme Lisans Programı, ORCID: 0000-0001-7054-2858, mehmetcem.bolen@atauni.edu.tr.
} 


\title{
A STUDY ON THE INTEREST OF BANKING SECTOR EMPLOYEES TO SOCIAL COMMERCE ${ }^{2}$
}

\begin{abstract}
Trade is one of the long-standing fields in human life. Developments in the fields of communication and technology from the past to the present have created different grounds for trade. Social commerce is one of the developing new trade environments of today that emerges at the intersection of social media platforms and commercial activities. In this study, the interests of the banking sector employees on social trade are examined by comparing based on demographic characteristics. Survey method was preferred for data collection from participants. In the pilot study, 81 bank staffs participated in the study. Following the pilot study, Following the pilot study, 402 participants answered the questions in the questionnaire developed for banking sector employees. Factor analysis was performed on the responses and five different interest topics were identified in addition to general interest. As a result of the analyzes, the differences between the demographic characteristics of the participants were examined according to the five different interests. As a result of this study, it was concluded that the social commerce interests of young participants were higher than those of other demographic characteristics. Furthermore, it was also concluded that female participants have more interest to social commerce activities in terms of gender characteristics.
\end{abstract}

Keywords: Social Commerce, S-Commerce, Social Media, E-Commerce, Mobile Commerce.

\section{GİRIŞ}

Günümüzün yaygın alışveriş ortamlarından biri olan e-ticaret ile kullanıcıların tanıştığı ilk zamanlarda e-ticaret platformları üzerindeki çalışmalar ürün ve hizmet odaklı şekilde gerçekleşmekteydi. Artan nüfus, yüksek internet kullanım oranı, çeşitlenen alternatif ödeme sistemleri, gelişmiş lojistik destek sistemleri gibi unsurlar kısa sürede e-ticareti en hızlı büyüyen alanlardan biri haline getirmiştir (Demirdöğmez, Gültekin ve Taş, 2018, s. 2218). Son yıllarda ise internet teknolojileri alanındaki gelişmeler doğrultusunda çift yönlü iletişim sağlayan Web 2.0 teknolojisiyle birlikte internet kullanıcılarının vazgeçilmezlerinden biri olan sosyal medya platformlanı yaygınlaşmaya başlamıştır. Sosyal medyanın insan hayatına girmesiyle birlikte e-ticaret özellikleri ve kullanım şekillerinde de değişim başladı. Özellikle sosyal medya kullanım oranlarının artışılla birlikte e-ticaret şirketleri kullanıcıların hangi ürün ve hizmetlere ilgi duyduğunu belirleyebilmekte, bu kapsamda kullanıcının satın alma ihtimali yüksek olan ürünleri önerebilmektedir. Sosyal medyadan e-ticaret alanında faydalanılması sonucunda geleneksel ticaret yöntemlerine göre satışlar olumlu yönde etkilenebilmektedir. Sosyal medya üzerindeki bu ticaret faaliyetleri sosyal ticaret olarak değerlendirilebilmektedir.

\footnotetext{
${ }^{2}$ This article is based on a master's thesis entitled "A Study on the Interest of Banking Sector Employees to Social Commerce" prepared by Murat Can AKTAŞ under the consultancy of Associated Professor Dr. Ersin KARAMAN.
} 
Özellikle sosyal medya platformları aracılığıyla gelişmeye devam eden sosyal ticaret alanı bazı kullanıcılar tarafindan tercih edilirken, bazı kullanıcılar tarafindan ise tercih edilmemektedir ve bu çalışmada kullanıcılar arasındaki ilgi farklılıkları sektör bazlı olarak incelenecektir.

\section{ARAŞTIRMANIN KONUSU VE AMACI}

Sosyal medyanın hayatımıza girmesiyle birlikte firma ve müşteri arasında kurulan iletişim kolaylaşmış, e-ticaretin yöntemleri ve sosyal medyanın kullanım şekillerinde de hızlı bir dönüşüm başlamıştır (Ying, 2012, ss. 47-48). Bu dönüşüm neticesinde ortaya çıkan sosyal ticaret olgusu, sosyal ağ platformlarının e-ticaret faaliyetleri kapsamında kullanılmasını ifade etmektedir (Zhong, 2012, s. 164). Sosyal ticaret, günümüzde e-ticaret faaliyetlerinin sosyal ağlar üzerinden gerçekleştirilebilmesi haricinde, reklamlar aracılığıyla tüketicinin satın alabileceği ürün/hizmet sayfasına yönlendirilmesi ve bir ürün/hizmet hakkında kullanıcıların fikir alışverişinde bulunabildikleri ortam olarak da bilinmektedir. Sosyal ağ kullanıcılarının bir kısmı sosyal ticaret ortamında sunulan bu özelliklerden faydalanabildiği gibi, bir kısmı ise sosyal ticaret ortamlarından uzak durmayı tercih edebilmektedir.

Literatürde sosyal ticaret kullanımı ile ilgili çalışmalar ağırlıklı olarak demografik ya da kültürel farklılıkları dikkate almadan, genel tüketici kitlesi üzerinde gerçekleştirilmiştir (örn. Söyleyici ve Bozkurt, 2017; Özgiden, 2013). Öte yandan sosyal ticaret kullanmak için dijital ve finans dünyasının temel araçlarını belirli bir seviyede kullanmak gereklidir. Örneğin sosyal ticaret platformuna giriş yapmak için ilgili platformda hesap açılması ve söz konusu platformun nasıl kullanılacağının bilinmesi gereklidir. Ya da sosyal ticaret platformunda alışveriş yapabilmek için EFT ya da havale gibi temel bankacılık işlemlerini gerçekleştirme becerisine sahip olunmalıdır. Bu yüzden dijital ve finans araçlarını kullanabilme becerisi, sosyal medya platformları üzerinden alışveriş yapmak için önemlidir. Kişilerin dijital ve finansal okuryazarlık seviyeleri ise eğitim, yaş veya cinsiyet gibi demografik özellikler ile yakın ilişkilidir. Dolayısıyla eğitim, yaş ve cinsiyet gibi temel demografik değişkenler dikkate alınmadan oluşturulan örneklemler ile yapılan çalışmalar, örneklemdeki kişilerin dijital ve finansal okuryazarlıklarının değişkenlik göstermesine ve analiz sonuçlarına kuşkuyla bakılmasına yol açmaktadır. $\mathrm{Bu}$ sorunun önüne geçmek için dijital ve finansal okur yazarlık seviyeleri birbirine benzer katılımcılardan oluşan bir örneklem kitlesi belirlemek gerekmektedir. $\mathrm{Bu}$ bağlamda özellikle ödeme sistemleri ve para transferi işlemleri hakkında müşterileri ile sürekli iletişim halinde olmaları ve elektronik ticaret ortamlarındaki ödeme, ödeme itirazı ve iade işlemleri ile ilgili tüketici şikayetleri ile karşılaşmalarından ötürü bankacılık sektörü çalışanları dijital ve finansal okuryazarlık açısından birbirine benzer özellikler göstermektedirler. Belirli bir seviyenin üzerinde dijital ve finansal okuryazarlık becerisine sahip bankacılık sektöründe çalışan kişilerden oluşan homojen bir örneklem ile yapılan bir çalışmada ortaya çıkan bulguların daha güvenilir ve net olacağı düşünülmektedir. Ayrıca bankacılık sektörü çalışanlarının 
sosyal ticaret faaliyetlerine ilgileri ortaya konularak sektör bazında kişilerin görüşlerinin yansıtılması amaçlanmaktadır. Elde edilecek sonuçların, sektör bazında sosyal ticarete yapılacak diğer çalışmalarda karşılaştırmalar yapılarak yeni çıkarımlarda bulunulmasına zemin hazırlayacağı düşünülmektedir. Bütün bu sebeplerden ötürü çalışmanın örneklemi olarak bankacılık sektörü çalışanları seçilmiştir.

Çalışmanın katılımcıları bankacılık sektöründe çalışan personellerden oluşmaktadır. Analizler sonucu elde edilen bulgular 1şı̆̆ında bankacılık sektörü çalışanlarının sosyal ticaret faaliyetleri tercihleri noktasında demografik bilgilerine göre gösterdikleri ilgi farklılıklarının ortaya konulması amaçlanmaktadır. Sosyal ticaretin gittikçe gelişmesi ve bu alanda yapılan araştırma sayısının henüz nispeten az olması sebebiyle çalışma sonuçlarının gerek akademik gerekse iş dünyasına değerli katkılar sunacağı düşünülmektedir. Çalışma kapsamında sosyal ticaret faaliyetlerine karşı katılımcıların ilgilerinin incelenmesi aşamasında belirlenen araştırma sorusu şu şekildedir:

- Katılımcıların sosyal ticarete karşı ilgileri (genel ilgi, reklam, güven, deneyim, ürün ve tercih ilgileri) ile demografik özellikleri (yaş, cinsiyet, medeni durum, öğrenim durumu ve net gelir) arasında anlamlı bir farklılık var midir?

\section{SOSYAL TICARET VE KAPSAMI}

Sosyal ticaret genel hatları itibariyle, e-ticaret ile ilgili gerçekleştirilen faaliyetlerin Web 2.0 yazılımları desteğiyle sosyal ağ platformları üzerinde gerçekleştirilmesi olarak açıklanmaktadır (Liang ve Turban, 2011, s. 6). Ancak ticari hedefler, müşteri bağlantısı ve sistem etkişimi açısından sosyal ticaret ve e-ticaret arasında ciddi farklılıklar bulunmaktadır (Huang ve Benyoucef, 2013, s. 247). Sosyal ticarette alışveriş deneyiminin paylaşılması ve sosyal etkileşimin desteklenmesi gibi unsurlar öne çıkarken (Liang ve Turban, 2011, s. 6), e-ticarette ürünle ilgili bilgiler ve kişiselleştirilmiş alışveriş deneyimi ön plandadır (Huang ve Benyoucef, 2013, s. 247). Bununla birlikte e-ticaretin aksine sosyal ticarette tüketici anında satıcı rolüne geçebilir (Jang, Ko, ve Kim, 2013, s. 2939). Ayrıca sosyal ticarette, e-ticaret platformlarına nazaran tüketicilerin kendilerini ifade etmelerini sağlayan ve birbirleri arasında deneyimlerini paylaşabilecekleri daha fazla özellik mevcuttur (Gibreel, AlOtaibi, Jeon ve Yoo, 2015, s. 1).

Özellikle son y1llarda sosyal medyanın ve e-ticaret faaliyetlerinin yaygınlaşmasıyla birlikte sosyal ticaret alanına gösterilen ilgide artış görülmektedir. Güneydoğu Asya ülkelerinde yapılan bir araştırmaya göre tüketicilerin \%26's1 son üç ayda en az bir ürünü sosyal medya kanallarından görüp satın almaya karar vermiştir (Econsultancy, 2019, s. 12). Bir başka araştırmada ise 16-24 yaş arası sosyal ağ kullanıcılarının \%24'ü, 25-34 yaş arası kullanıcıların ise \%32'si bir markanın veya ürünün sosyal medyada beğenildiğini görmenin kendilerini satın almaya teşvik ettiği ifade edilmiştir (Kemp, 2020). Sosyal medya ve e-ticaretin 
kesiştiği nokta olan sosyal ticaretin 6 boyutu bulunmakta olup, bu boyutlar şu şekildedir (Marsden, 2010, Akt: Orun, 2017, ss. 56-57):

- Sosyal Alışveriş: Kullanıcıların sosyal medya platformları üzerinden birbirleriyle iletişime geçebildikleri ve aynı zamanda ticaret faaliyetleri gerçekleştirebildikleri boyut olarak ifade edilmektedir.

- Derecelendirme ve Yorumlama: Kullanıcıların bir ürün veya hizmet ile ilgili deneyimlerini geri bildirimler üzerinden iletebildiği boyuttur. Kullanıcının deneyimi ile ilgili geri bildirim ve yorumda bulunma boyutları sayesinde diğer kullanıcılar da ürünü satın alıp almama konusunda daha kolay karar verebilmektedir.

- Önerilerde Bulunma: Öneride bulunma boyutunda bir ürünü deneyimleyen kullanıcı, çevresinde tanıdığı bir kullanıcıya o ürünü kullanmasını önerebilmektedir. Derecelendirme ve yorumlama boyutu ile önerilerde bulunma boyutu arasındaki fark; önerilerde bulunma boyutunda kullanıcı herkese değil, belirli kişilere önerilerde bulunabilmektedir.

- Forum ve Topluluk Ortamları: Kullanıcıların iletişim halinde olabildikleri ortamlardan biri olan forumlarda kullanıcılar, ürünler hakkında bilgi alışverişinde bulunabilmektelerdir. Böylece, kullanıcıların satın almayı düşündükleri ürün için daha iyi fikir sahibi olabilmeleri sağlanmaktadır.

- Sosyal Medya Optimizasyonu: Sosyal medya kullanımının yaygınlaşmasıyla birlikte sosyal medya kullanıcılarının sosyal medya platformları üzerinden e-ticaret sitelerine yönlendirilmesini sağlayan boyuttur. Kullanıcıları sosyal medya platformları üzerinden e-ticaret sitelerine yönlendiren firmalar satışların artırılmasını hedeflemektedir.

- Sosyal Reklamlar ve Sosyal Uygulamalar: Sosyal Medya Optimizasyonu boyutuna benzer şekilde Sosyal Reklamlar ve Sosyal Uygulamalar boyutunda firmalar sosyal medya platformlarında ücretli reklamlar yayınlayabilmektedir. Ayrıca çeşitli kampanyaların duyurularını da sosyal medya platformları aracılığıly paylaşabilmektelerdir. Sosyal Medya Optimizasyonu boyutunda olduğu gibi bu boyutta da firmalar satışların artırılmasını hedeflemektedir.

\section{SOSYAL TİCARET İLE İLGILİ YAPILAN ÇALIŞMALAR}

Son yıllarda farklı disiplinlerden birçok araştırmacı sosyal ticaret üzerine araştırmalar yapmaktadır. Örneğin; Chen, Su ve Widjaja (2016, s. 57) tarafından yapılan çalışmada Facebook platformunu ticaret faaliyetleri için kullanan üyelerin alış ve satış grubu üzerindeki faaliyetlerinde reklam içerikleri ve beğeni sayılarının satın alma dürtüsüne etkileri araştırılmıştır. Çalışma sonucunda reklam metinlerinin ve beğeni sayılarının tüketicilerin satın alma dürtüsünü artırabileceği öne sürülmüştür. Mohapatra ve Lokhande (2014), sosyal ticaret faaliyetlerinin iki açıdan 
Aktaș, M. C., Karaman, E., Bölen, M. C. $\quad$ DË̈ SBE Dergisi, Cilt: 23, Sayl: 2

önemli yararı olduğunu belirtmiş̧ir. Bunlardan biri müşteriler için yararlar, diğeri ise perakendeciler için yararlardır. Müşteriler için yararları; bilgiye ücretsiz erişim, zaman tasarrufu, daha iyi ürünlere erişim ve güvenilir ortam olarak açıklanmaktadır. Perakandeciler için yararları ise; müşterilerin sadakat durumu, gelirlerin artması, ürünün iyileştirilerek iade oranının düşürülmesi, alışveriş deneyiminin kişiselleştirilerek kullanıcının tanınması, yeni kitleye erişim ve web etkisindeki artış şeklinde sıralanmaktadır (Akt: Akar, 2018, ss. 158-160). Durukal, Doğaner ve Armağan (2019) tarafından yayınlanan çalışmada e-ticaret faaliyetlerine katılan kişilerin sosyal medya platformları üzerinden gerçekleşen pazarlama faaliyetlerinin e-sadakate karşı etkileri araştırılmıştır. $\mathrm{Bu}$ araştırma sonucuna göre e-ticaret faaliyetlerine katılanlar arasında kadınların e-sadakatlerinin daha iyi seviyede olduğu, e-ticareti erkeklere göre daha fazla tercih edebildikleri ifade edilmektedir. Özgiden (2013) kullanıcıların sosyal ticarete katılım durumlarının incelenmesi amacıyla hazırladığı çalışmaya göre satın alma şartı olmaksızın kullanıcıların bir ürün veya hizmeti beğenip paylaşabildikleri sonucuna varmıştır. Rad ve Benyoucef (2010) çalışmasında sosyal medyanın, tüketicilerin satın alma aşamasındaki kararları üzerine etkileri değerlendirilmiş ve sosyal ticaret faaliyetlerinde kullanıcı etkileşiminin önemli yere sahip olduğu belirtilmiştir. Söyleyici ve Bozkurt (2017) tarafından yayınlanan çalışmada sosyal medya platformlarının, kullanıcıların satın alma öncesi ve satın alma sonrası davranışlarda demografik özelliklere göre farklılıklarının belirlenmesi amaçlanmıştır. Çalışma sonuçlarına göre satın alma öncesi ve satın alma sonrası davranışlar, yaş ve eğitim özellikleri açısından farklılık göstermektedir. Özeltürkay, Bozyiğit ve Gülmez (2017) tarafindan yayınlanan çalışmada ise Instagram üzerinden alışveriş yapan tüketicilerin satın alma davranışları incelenmiş ve alışveriş için Instagram'ı tercih etme nedenleri arasında; kapıda ödeme seçeneğinin bulunması, ürün gamı genişliği ve ürünlerin fiyat bakımından daha uygun olması gösterilmiş̧ir. Onurlubaş ve Öztürk (2018) ise çalışmasında, Instagram'da kullanılan yöntemlerin Y kuşağındaki kişilerin satın alma davranışıyla ilgili etkisini incelemiştir. Çalışma sonucunda görsel imaj, diğer tüketicilerin beğeni durumları, takipçi sayıları ve satıcının davranışı gibi kriterlerin satın alma davranışlarını etkilediği belirtilmiştir. Sarıyer ve Zümrüt (2017) tarafından yapılan çalışmada, kullanıcıların Instagram'da geçirdikleri süreye göre, reklamlardan etkilenme durumları araştırılmıştır. Çalışma sonucunda Instagram'da geçirilen süre bakımından; 2 saat ve üstü vakit geçiren kullanıcıların reklam içeriğgine karşı duyarlı oldukları ve reklam içeriklerine önem verdikleri aktarılmıştır. Ürgen (2019)'in çalışmasında ise sosyal medya platformlarında bulunan reklamların özellikle genç yaştaki tüketicilerin satın alma tarzlarında tutum, davranış ve satın alma niyetlerine olan etkileri araştırılmıştır. Çalışma sonucunda tüketicilerin sosyal medya platformlarında yer alan reklamlara yönelik tutumları ile satın alma tarzları arasında anlamlı bir ilişki bulunduğu belirlenmiştir. Salvatori ve Marcantoni (2015), tarafından yayınlanan çalışma kapsamında sosyal ticaret için bir literatür araştırması yapılmıştır. Araştırma sonuçlarına göre, özellikle 2010 - 2013 yılları arasında sosyal ticaret alanına gösterilen ilgide artış görülmüştür. Ayrıca, şirketlerin müşterilerle etkileşim halinde olması ve müşterilere önerilerde bulunabilmeleri için bir sosyal 
ticaret uygulamasına ihtiyaç duyulduğu da açıklanmıştır. Turgut (2016) tarafından yayınlanan çalışmada, sosyal medya platformlarında bulunan reklamların tüketicilerin satın alma niyetleri üzerindeki etkilerinin incelenmesi hedeflenmiştir. Çalışmada, sosyal medyanın, tüketicilerin satın alma niyetleri üzerinde etkiye sahip olduğu sonucuna ulaşılmıştır. Kavukçu (2018) tarafından yayınlanan çalışmada sosyal ă̆ platformlarında bulunan reklamların, tüketicilerin satın alma kararları konusunda etkiye sahip olup olmadığı incelenmiştir. Çalışmada, tüketicilerin satın alma kararlarında, sosyal ağ platformlarında yer alan reklamların etkisinin olduğu sonucuna ulaşılmıştır.

\section{METODOLOJİ}

\section{Veri Toplama Aracı}

Araştırmada nicel araştırma yöntemlerinden korelasyon araştırma deseni tercih edilmiştir. Korelasyon deseninde iki veya daha fazla değişken ya da bazı puan grupları arasındaki ilişkiyi ölçmek ve tanımlamak için ilişkisel istatistik kullanılmaktadır (Creswell, 2016, s.12). Çalışmada, farklı coğrafi bölgelerde bulunan bankacılık sektörü çalışanlarına ulaşılabilmesi için veri toplama aracı olarak anket tercih edilmiştir. Hazırlanan anket formları hem basılı hem elektronik olarak dağıtılmıştır. Basılı anketlerin dağıtılması sürecinde, farklı bankaların şubeleri ziyaret edilip çalışmanın içeriği açıklanarak çalışmaya gönüllü katılmak isteyen personellere anket verilmiştir. Personellerin iş süreçlerinin etkilenmemesi açısından, anketlerin geri toplanma işlemi çalışmaya gönüllü katılan personellerin anketi teslim alırken bildirdiği süre sonunda gerçekleştirilmiştir. Elektronik ortamda uygulanan ankette ise potansiyel katılımcıların e-postalarına davet linki gönderilmiştir ve bankacılık sektörü dışından girişlerin engellenmesi noktasında anket giriş sayfasına parola koruması tanımlanmıştır. Bu doğrultuda, anket uygulamasına gönüllü olarak katılan kullanıcıların yanıtları değerlendirmeye alınmıştır.

Ankette yer alan ifadelerin hazırlanması aşamasında literatürdeki çalışmalar incelenmiştir. Yapılan incelemeler sonucunda anket ifadeleri hazırlanırken katılımcıların sosyal ticaret yönelik ilgileri kapsamında; deneyim alt boyutu için Yüksel (2010) ve Karacan (2006), güven alt boyutu için Orun (2017) ile Küçükgöncü (2018), reklam alt boyutu için Küçükgöncü (2018), ürün alt boyutu için Alican ve Saban (2013), Yüksel (2010) ile Küçükgöncü (2018) ve tercih alt boyutu için Küçükgöncü (2018) çalışmalarındaki ölçekler sosyal ticaret bağlamına uyarlanmıştır. Ayrıca, incelenen bu çalışmalarda, ilgili ölçekler için güvenilirlik analizlerinin uygulandığg bilgisine ulaşılmıştır.

\section{Örneklem Seçimi}

Çalışmanın örneklemini bankacılık sektöründe çalışan kişiler oluşturmaktadır. Örneklem olarak bankacılık sektörü çalışanlarının seçilmesi, elektronik ticaret konusunda birbirine benzer bilgi seviyesine sahip olmalarıdır. Tüketicilerin e-ticarette ödeme, iade ve ödeme itirazları gibi adımlarda herhangi bir 
sorun yaşaması halinde genellikle bankacılık sektörü çalışanları destek vermektedir. $\mathrm{Bu}$ durum bankacılık sektörü çalışanlarının elektronik ortamda gerçekleştirilen ticaret faaliyetlerine karşı bilgi düzeylerinin benzer olmasını sağlamaktadır. Dolayısıyla bu örneklemin seçilmesi neticesinde demografik özellikler dışında bilgi seviyesi, bilgisayar fobisi gibi değişkenlerin etkisinin çalışmanın sonuçlarını yorumlarken çok daha az olması amaçlanmıştır.

Minimum katılımcı sayısı, Türkiye Bankalar Birliği'nin internet sitesi üzerinden ulaşılan, Türkiye'de bankacılık sektöründe çalışan toplam personel sayısına göre hesaplanmıştır. Mart 2019'a ait personel sayısının 190.908 olduğu görülmüsstür. Bu doğrultuda $\% 95$ güven seviyesi ve $\% 5$ hata payı bilgileriyle birlikte Emir ve Durmaz (2009, s. 27) tarafından hazırlanan çalışmadaki formül üzerinden yapılan hesaplamaya göre minimum 384 katılımcıya ulaşılması gerektiği belirlenmiştir. Aynı formül, pilot aşamadaki katılımcı sayısının belirlenmesi noktasında da kullanılmıştır.

Minimum katılımcı sayısının hesaplanmasında kullanılan formüle aşağıda yer verilmiştir (Emir ve Durmaz, 2009, s. 27):

$$
n=\frac{\mathrm{N} \cdot \mathrm{t}^{2} \cdot p \cdot q}{(\mathrm{~N}-1) \cdot d^{2}+t^{2} \cdot \mathrm{p} \cdot \mathrm{q}}
$$

n: Hesaplama sonucu örnekleme alınacak minimum kişi sayısı,

N: Evrendeki kişi sayısı (190.908),

$\mathrm{t}$ : Serbestlik derecesi ve yanılma düzeyine göre $\mathrm{t}$ tablosundaki değer $(1,96)$,

p: Araştırma konusu olayın görülme olasılı̆̆g $(0,5)$,

q: Araştırma konusu olayın görülmeme olasıllığ $(0,5)$, $(0,05)$.

d: Araştırma konusu olayın görülme olasılığına göre yapılmak istenen sapma

Çalışmanın veri toplama sürecinde pilot aşamada, bankacılık sektöründe çalışan 81 kişiye ulaşılmıştır ve çalışmanın konusundan bahsedilerek anket davet linki gönderilmiştir. Pilot aşamada toplanan verilere uygulanan güvenilirlik testi sonrasında toplam 402 kişi ankete katılım göstermiştir.

\section{ANALIZ}

Çalışmada verilerin toplanması aşamasında ankette bulunan ölçeklerin güvenilirliğinin ölçülmesi amacıyla öncelikle 81 katılımcı üzerinde pilot çalışma gerçekleştirilmiştir. Pilot çalışmaya katılan 81 katılımcıdan elde edilen yanıtlara göre gerçekleştirilen güvenilirlik testi sonuçlarında Cronbach's Alpha değeri 0,898 olarak hesaplanmıştır. $\mathrm{Bu}$ durum ankette kullanılan ölçeklerin güvenilir olduğuna işaret etmektedir. 
Pilot aşamadan sonra çalışmaya katılan katılımcılara ait demografik özelliklere Tablo 1 üzerinde yer verilmiştir.

Tablo 1: Katılımcıların Demografik Özellikleri

\begin{tabular}{|c|c|c|}
\hline Yaş & Frekans & Yüzde \\
\hline 25 Alt1 & 12 & 3,0 \\
\hline $25-34$ & 240 & 59,7 \\
\hline $35-44$ & 134 & 33,3 \\
\hline $45-54$ & 16 & 4,0 \\
\hline Toplam & 402 & 100,0 \\
\hline \multicolumn{3}{|l|}{ Cinsiyet } \\
\hline Erkek & 198 & 49,3 \\
\hline Kadın & 204 & 50,7 \\
\hline Toplam & 402 & 100,0 \\
\hline \multicolumn{3}{|l|}{ Medeni Durum } \\
\hline Evli & 270 & 67,2 \\
\hline Bekar & 132 & 32,8 \\
\hline Toplam & 402 & 100,0 \\
\hline \multicolumn{3}{|l|}{ Öğrenim Durumu } \\
\hline Lise & 23 & 5,7 \\
\hline Ön Lisans & 21 & 5,2 \\
\hline Lisans & 295 & 73,4 \\
\hline Yüksek Lisans & 63 & 15,7 \\
\hline Toplam & 402 & 100,0 \\
\hline \multicolumn{3}{|l|}{ Net Gelir Durumu } \\
\hline $0-2.200 \mathrm{TL}$ & 19 & 4,7 \\
\hline $2.201-4.200 \mathrm{TL}$ & 155 & 38,6 \\
\hline $4.201-6.400 \mathrm{TL}$ & 131 & 32,6 \\
\hline $6.401-8.600 \mathrm{TL}$ & 55 & 13,7 \\
\hline 8.601 TL ve üzeri & 42 & 10,4 \\
\hline Toplam & 402 & 100,0 \\
\hline \multicolumn{3}{|l|}{ Görev } \\
\hline BT Personeli & 53 & 13,2 \\
\hline Çağrı Merkezi Temsilcisi & 2 & 0,5 \\
\hline Gişe Personeli & 29 & 7,2 \\
\hline Satış Temsilcisi & 188 & 46,8 \\
\hline Servis / Operasyon & 73 & 18,2 \\
\hline Yönetici & 57 & 14,2 \\
\hline Toplam & 402 & $\mathbf{1 0 0 , 0}$ \\
\hline \multicolumn{3}{|l|}{ Sosyal Medya Kullanımı } \\
\hline LinkedIn & 131 & 12,9 \\
\hline Twitter & 187 & 18,4 \\
\hline Instagram & 330 & 32,5 \\
\hline YouTube & 131 & 12,9 \\
\hline Facebook & 237 & 23,3 \\
\hline Toplam & 1016 & 100,0 \\
\hline \multicolumn{3}{|l|}{ E-Ticaret Faaliyetlerine Katılım } \\
\hline Evet & 362 & 90,0 \\
\hline Hayır & 40 & 10,0 \\
\hline Toplam & 402 & $\mathbf{1 0 0 , 0}$ \\
\hline \multicolumn{3}{|l|}{ Son E-Ticaret Alışverişi } \\
\hline Son 24 saat içinde & 39 & 9,7 \\
\hline Son 3 gün içinde & 60 & 14,9 \\
\hline Son 7 gün içinde & 75 & 18,7 \\
\hline Son 30 gün içinde & 131 & 32,6 \\
\hline Son 90 gün ve daha uzun süre içinde & 57 & 14,2 \\
\hline
\end{tabular}


Aktaș, M. C., Karaman, E., Bölen, M. C.

DEÜ SBE Dergisi, Cilt: 23, Sayl: 2

\begin{tabular}{lcc}
\hline Hiçbir zaman & 40 & 10,0 \\
\hline Toplam & $\mathbf{4 0 2}$ & $\mathbf{1 0 0 , 0}$ \\
\hline Sosyal Medya Üzerinden Alışveriş & 126 & 31,3 \\
\hline Evet & 276 & 68,7 \\
\hline Hayır & $\mathbf{4 0 2}$ & $\mathbf{1 0 0 , 0}$ \\
\hline Toplam & 5 & 1,2 \\
\hline Son Sosyal Ticaret Alışverişi & 9 & 2,2 \\
\hline Son 24 saat içinde & 19 & 4,7 \\
\hline Son 3 gün içinde & 44 & 10,9 \\
\hline Son 7 gün içinde & 60 & 14,9 \\
\hline Son 30 gün içinde & 265 & 65,9 \\
\hline Son 90 gün ve daha uzun süre içinde & $\mathbf{4 0 2}$ & $\mathbf{1 0 0 , 0}$ \\
\hline Hiçbir zaman & &
\end{tabular}

Tablo 1 incelendiğinde 362 katılımcının $(\% 90,0)$ e-ticaret faaliyetlerine katılım gösterdiği; e-ticaret faaliyetlerine son katılım konusunda ise 131 katılımcının $(\% 32,6)$ son 30 gün içinde e-ticaret faaliyetlerine katıldığı görülmektedir. Ayrıca, 126 katılımcının $(\% 31,3)$ sosyal ticaret faaliyetlerine katılım gösterdiği; sosyal ticaret faaliyetlerine son katılım konusunda ise 60 katılımcının $(\% 14,9)$ son 90 gün ve daha uzun süre içinde sosyal ticaret faaliyetlerine katıldığ ifade edilebilmektedir.

Ankette katılımcılara sosyal ticarete yönelik ilgileri hakkında yöneltilen ifadelerin ortalama ve standart sapma değerleri Tablo 2'de gösterilmektedir. Katılımcılara yöneltilen ifadelerde ' 1 ' değeri "Kesinlikle Katılmıyorum" anlamını taşırken; '5' değeri ise "Kesinlikle Katılıyorum" anlamını ifade etmektedir. Katılımcıların yanıtladıkları ifadelerde 1 ile 5 aralığındaki bu değerlerin ortalaması hesaplanarak ilgili ifadeleri hangi düzeyde destekledikleri görülebilmektedir. Tablodaki değerler hesaplanmadan önce 15, 16, 17, 18, 19, 20, 21, 22, 23 ve 25 . ifadelerin negatif anlama sahip olmalarından dolayı bu ifadelerin yanıtları ters çevrilerek kodlanmıştır.

Tablo 1: İfadelerin Ortalama ve Standart Sapma Değerleri

\begin{tabular}{|l|l|r|r|r|}
\hline No & \multicolumn{1}{|c|}{ İfade } & N & \multicolumn{1}{|c|}{ Ortalama } & $\begin{array}{c}\text { Standart } \\
\text { Sapma }\end{array}$ \\
\hline 15 & Sosyal medya platformlarında alışveriş yapmayı karmaşık buluyorum & 402 & 3,40 & 1,279 \\
\hline 16 & Sosyal medya platformları üzerinden alışveriş yapmayı sıkııı buluyorum & 402 & 3,35 & 1,248 \\
\hline 17 & $\begin{array}{l}\text { Sosyal medya platformları üzerinden ürünü denemeden, fotoğrafları } \\
\text { inceleyerek satın almayı sevmiyorum }\end{array}$ & 402 & 2,67 & 1,299 \\
\hline 18 & $\begin{array}{l}\text { Sosyal medya platformları üzerinden satın alınan ürünlerin gösteriş } \\
\text { amaçlı alındığını düşünüyorum }\end{array}$ & 402 & 3,50 & 1,189 \\
\hline 19 & $\begin{array}{l}\text { Sosyal medya platformları üzerinden alışveriş yaptığımda hayal } \\
\text { kırılığına uğrayacağımı düşünüyorum }\end{array}$ & 402 & 2,77 & 1,153 \\
\hline 20 & $\begin{array}{l}\text { Sosyal medya platformları üzerinden alışveriş yaptı̆̆ımda } \\
\text { arkadaşlarımdan sosyalleşme açısından uzaklaşacağımı düşünüyorum }\end{array}$ & 402 & 3,94 & 1,028 \\
\hline 21 & $\begin{array}{l}\text { Sosyal medya platformları üzerinden yayınlanan bazı ürün reklamlarının } \\
\text { toplumun giyim tarzını zedelediğini düşünüyorum }\end{array}$ & 402 & 3,19 & 1,262 \\
\hline 22 & $\begin{array}{l}\text { Sosyal medya platformunda satın almayı düşündüğ̈̈m bir ürünün satıcı } \\
\text { tarafından kısa zamanda gönderileceğini düşünmüyorum }\end{array}$ & 402 & 3,11 & 1,113 \\
\hline 23 & $\begin{array}{l}\text { Sosyal medya platformlarında satılan ürünlerin fotoğrafları ile adresime } \\
\text { gönderilen ürünün farklı olabileceğini düşünüyorum }\end{array}$ & 402 & 2,54 & 1,121 \\
\hline
\end{tabular}




\begin{tabular}{|c|c|c|c|c|}
\hline 24 & $\begin{array}{l}\text { Mağazaların reyonlarında bulunan ürünleri incelemeye firsat } \\
\text { bulamadığım için sosyal medya platformlarında satılan ürünleri } \\
\text { incelemeyi tercih ediyorum }\end{array}$ & 402 & 3,09 & 1,293 \\
\hline 25 & $\begin{array}{l}\text { Sosyal medya platformlarında alışveriş yaparken kişisel bilgilerimin } \\
\text { gizliliği konusunda endişe duyuyorum }\end{array}$ & 402 & 2,32 & 1,106 \\
\hline 26 & $\begin{array}{l}\text { Sosyal medya platformları üzerinden alışveriş yapma konusunda } \\
\text { kendime güveniyorum }\end{array}$ & 402 & 3,42 & 1,080 \\
\hline 27 & $\begin{array}{l}\text { Sosyal medya platformları üzerinden alışveriş yapmayı kimseden yardım } \\
\text { almadan kendi kendime öğrenebileceğimi düşünüyorum }\end{array}$ & 402 & 4,09 & 0,991 \\
\hline 28 & $\begin{array}{l}\text { Herkes sosyal medya platformları üzerinden alışveriş yapmayı } \\
\text { öğrenmelidir }\end{array}$ & 402 & 2,86 & 1,234 \\
\hline 29 & $\begin{array}{l}\text { Sosyal medya platformları üzerinden satılan ürünleri incelemek hoşuma } \\
\text { gider }\end{array}$ & 402 & 3,32 & 1,186 \\
\hline 30 & $\begin{array}{l}\text { S1kıldı̆̆ımda sosyal medya platformları üzerinden satılan ürünleri } \\
\text { incelemeyi seviyorum }\end{array}$ & 402 & 3,13 & 1,283 \\
\hline 31 & $\begin{array}{l}\text { Toplum içinde yalnız kaldığımda sosyal medya platformlarında satılan } \\
\text { ürünleri incelerim }\end{array}$ & 402 & 2,64 & 1,182 \\
\hline 32 & $\begin{array}{l}\text { Sosyal medya platformları üzerinden arkadaşlarımın satın aldıkları } \\
\text { ürünleri incelemeyi severim }\end{array}$ & 402 & 2,69 & 1,209 \\
\hline 33 & $\begin{array}{l}\text { Sosyal medya platformları üzerinden yayınlanan ürün reklamlarını } \\
\text { incelerim }\end{array}$ & 402 & 2,63 & 1,190 \\
\hline 34 & $\begin{array}{l}\text { Sosyal medya platformlarında yayınlanan ürün reklamları ilgimi } \\
\text { çekmektedir }\end{array}$ & 402 & 2,60 & 1,186 \\
\hline 35 & $\begin{array}{l}\text { Sosyal medya platformları üzerinden yayınlanan bir reklamdaki ürünü } \\
\text { beğendiğimde reklama tıklarım }\end{array}$ & 402 & 2,83 & 1,255 \\
\hline 36 & $\begin{array}{l}\text { Sosyal medya platformlarında satıcıların alıcıları dinleyerek ihtiyaçlara } \\
\text { özel çözümler sunabileceklerini düşünüyorum }\end{array}$ & 402 & 2,92 & 1,149 \\
\hline 37 & $\begin{array}{l}\text { Sosyal medya platformlarında satılan ürünlerin fiyatlarının piyasaya } \\
\text { göre daha uygun olduğunu düşünüyorum }\end{array}$ & 402 & 3,11 & 1,144 \\
\hline 38 & $\begin{array}{l}\text { Sosyal medya platformları üzerinden satılan ürünler hakkında } \\
\text { kampanyalardan haberdar olduğumda mutlu olurum }\end{array}$ & 402 & 2,98 & 1,146 \\
\hline 39 & $\begin{array}{l}\text { Sosyal medya platformlarındaki ürün reklamları sayesinde aradığım } \\
\text { ürünü bulabiliyorum }\end{array}$ & 402 & 2,90 & 1,140 \\
\hline 40 & $\begin{array}{l}\text { Sosyal medya platformları üzerinden alışveriş konusunda ileri düzey } \\
\text { bilgi sahibiyim }\end{array}$ & 402 & 3,01 & 1,132 \\
\hline 41 & $\begin{array}{l}\text { Sosyal medya platformları üzerinden alıșveriş yapma konusunda bana } \\
\text { soru sorulduğunda kendimi iyi hissederim }\end{array}$ & 402 & 2,54 & 1,082 \\
\hline 42 & $\begin{array}{l}\text { Sosyal medya platformlarında satılan bir ürün için yorum yazmayı } \\
\text { seviyorum }\end{array}$ & 402 & 2,36 & 1,144 \\
\hline 43 & $\begin{array}{l}\text { Sosyal medya platformlarında yayınlanan ürün reklamları sayesinde } \\
\text { modaya uygun ürünler satın alabileceğimi düşünüyorum }\end{array}$ & 402 & 2,79 & 1,133 \\
\hline 44 & $\begin{array}{l}\text { Sosyal medya platformları üzerinden ürün satın alarak arkadaş çevremi } \\
\text { genișletebileceğimi düşünürüm }\end{array}$ & 402 & 1,88 & 0,959 \\
\hline 45 & $\begin{array}{l}\text { Sosyal medya platformlarında satılan bir ürün hakkında arkadaşlarımla } \\
\text { fikir alışverişinde bulunmak hoşuma gider }\end{array}$ & 402 & 2,94 & 1,183 \\
\hline 46 & $\begin{array}{l}\text { Sosyal medya platformları üzerinden bir ürün satın alırsam, ürünü } \\
\text { aldığım satıcıyı arkadașlarıma tavsiye edebilirim }\end{array}$ & 402 & 3,39 & 1,118 \\
\hline 47 & $\begin{array}{l}\text { Sosyal medya platformlarında bir ürün satın alırsam, ürünün } \\
\text { arkadaşlarım tarafindan beğenilmesi beni mutlu eder }\end{array}$ & 402 & 3,29 & 1,167 \\
\hline
\end{tabular}

\section{Güvenilirlik Testi}

Çalışmada kullanılan ölçeklerin güvenilirliğinin ölçülmesi amacıyla SPSS üzerinde Cronbach's Alpha yöntemi kullanılmıştır ve sonuçlar Tablo 3'te paylaşılmıştır. 
Aktaș, M. C., Karaman, E., Bölen, M. C. DEÜ SBE Dergisi, Cilt: 23, Sayl: 2

Tablo 2: Güvenilirlik Testi

\begin{tabular}{ccc}
\hline Cronbach's Alpha & $\begin{array}{c}\text { Cronbach's Alpha } \\
\text { (Standardize Edilmiş) }\end{array}$ & N \\
\hline 0,935 & 0,934 & 33 \\
\hline Tablo & Cron & \\
\hline
\end{tabular}

Tablo 3'te görüldüğ̈̈ üzere Cronbach's Alpha yöntemi sonucunda 0,935 değeri hesaplanmıştır. Pilot aşamada elde edilen değerden sonra bu aşamada elde edilen değerin de 0,7 'den büyük olması verilerin güvenilir olduğunu göstermektedir

\section{Normallik Testi}

Genel ilgi ve alt ilgi başlıkları için yapılan normallik testlerinin sonucu Tablo 4'te gösterilmektedir. Katılımcı sayısının 30'dan fazla olması nedeniyle Kolmogorov-Smirnov alanındaki değerler dikkate alınmaktadır.

Tablo 3: Normallik Testi

\begin{tabular}{lccc|ccc}
\hline & \multicolumn{3}{c|}{ Kolmogorov-Smirnov } & \multicolumn{3}{c}{ Shapiro-Wilk } \\
\hline & İstatistik & df & Sig. & İstatistik & df & Sig. \\
\hline Genel İlgi & 0,044 & 402 & 0,055 & 0,997 & 402 & 0,565 \\
\hline Reklam & 0,073 & 402 & 0,000 & 0,982 & 402 & 0,000 \\
\hline Güven & 0,053 & 402 & 0,009 & 0,991 & 402 & 0,016 \\
\hline Deneyim & 0,072 & 402 & 0,000 & 0,990 & 402 & 0,007 \\
\hline Ürün & 0,077 & 402 & 0,000 & 0,983 & 402 & 0,000 \\
\hline Tercih & 0,121 & 402 & 0,000 & 0,958 & 402 & 0,000 \\
\hline
\end{tabular}

Kolmogorov-Smirnov değerine göre sadece genel ilgi değerinin normal dağılım göstermesi nedeniyle doğru analizlerin yapılabilmesi açısından ilgi değerleri için çarpıklık ve basıklık değerlerinin de incelenmesine karar verilmiştir. Çarpıklık ve basıklık değerleri Tablo 5'te gösterilmektedir.

Tablo 4: Çarpıklık ve Basıklık Değerleri

\begin{tabular}{lc|cc|cc}
\hline & $\mathbf{N}$ & \multicolumn{2}{c|}{ Skewness } & \multicolumn{2}{c}{ Kurtosis } \\
\hline & İstatistik & İstatistik & Std. Hata & İstatistik & Std. Hata \\
\hline Genel İlgi & 402 & $-0,047$ & 0,122 & $-0,244$ & 0,243 \\
\hline Reklam & 402 & 0,103 & 0,122 & $-0,623$ & 0,243 \\
\hline Güven & 402 & $-0,167$ & 0,122 & $-0,388$ & 0,243 \\
\hline Deneyim & 402 & $-0,211$ & 0,122 & $-0,181$ & 0,243 \\
\hline Ürün & 402 & 0,380 & 0,122 & 0,113 & 0,243 \\
\hline Tercih & 402 & $-0,333$ & 0,122 & $-0,692$ & 0,243 \\
\hline
\end{tabular}

Eğer çarpıklık (skewness) ve basıklık (kurtosis) değerleri -1 ve +1 arasındaysa ilgili verilerin normal dağılım gösterdiği ifade edilebilir (Huck, 2012; Akt: Örün, Orhan, Dönmez ve Kurt, 2015, s. 68). Bazı kaynaklarda ise normal dağılım şartı olarak gösterilen bu değer aralığı değişmektedir. Çarpıklık (skewness) ve basıklık (kurtosis) değerlerinin $-1,5$ ve $+1,5$ aralığında olması normal dağılımın kabul edilebilmesi için yeterlidir (Tabachnick ve Fidell, 2013; Akt: Erbay ve Beydoğan, 2017, s. 250). Tablo 5'te yer alan değerler incelendiğinde çarpıklık (skewness) ve basıklık (kurtosis) değerleri -1 ve +1 aralığındadır. Buna göre tüm ilgi değerlerinin normal dağıldığ 


\section{Faktör Analizi}

Çalışmadaki ifadeler arasında anlam bütünlügünün korunabilmesi ve birbirine yakın olanların gruplandırılabilmesi amacıyla faktör analizi gerçekleştirilecektir. Verilerin faktör analizi için uygun olup olmadığı noktasında Kaiser-Meyer-Olkin değerlerinin incelenmesi gerekmektedir. Bu kapsamda KaiserMeyer-Olkin değerlerine Tablo 6'da yer verilmektedir.

Tablo 5: Kaiser-Meyer-Olkin Değerleri

\begin{tabular}{llr}
\hline Kaiser-Meyer-Olkin. & & 0,929 \\
\hline \multirow{3}{*}{ Bartlett's Test of Sphericity } & Approx. Chi-Square & 7183,646 \\
\cline { 2 - 3 } & Df & 528 \\
\cline { 2 - 3 } & Sig. & 0,000 \\
\hline
\end{tabular}

Kaiser-Meyer-Olkin değerinin 0,929 ve Bartlett's testinde $p$ değerinin 0,000 olarak hesaplanmasıyla birlikte verilerin faktör analizi için uygun olduğu görülmektedir.

Çalışmada katılımcıların yanıtladığ ifadelere yönelik gerçekleştirilen faktör analizi sonuçlarına Tablo 7'de yer verilmiştir.

Tablo 6: Faktör Analizi

\begin{tabular}{|c|c|c|c|c|c|}
\hline \multirow{2}{*}{ İfadeler } & \multicolumn{5}{|c|}{ Faktörler } \\
\hline & Reklam & Güven & Deneyim & Ürün & Tercih \\
\hline İfade33 & 0,882 & & & & \\
\hline İfade34 & 0,868 & & & & \\
\hline İfade35 & 0,743 & & & & \\
\hline İfade31 & 0,527 & & & & \\
\hline İfade32 & 0,496 & & & & \\
\hline İfade38 & 0,325 & & & & \\
\hline İfade19 & & 0,807 & & & \\
\hline İfade18 & & 0,790 & & & \\
\hline İfade23 & & 0,772 & & & \\
\hline İfade17 & & 0,741 & & & \\
\hline İfade16 & & 0,728 & & & \\
\hline İfade22 & & 0,711 & & & \\
\hline İfade15 & & 0,708 & & & \\
\hline İfade21 & & 0,681 & & & \\
\hline İfade25 & & 0,521 & & & \\
\hline İfade 20 & & 0,490 & & & \\
\hline İfade27 & & & $-0,678$ & & \\
\hline İfade46 & & & $-0,639$ & & \\
\hline İfade37 & & & $-0,598$ & & \\
\hline İfade47 & & & $-0,584$ & & \\
\hline İfade26 & & & $-0,455$ & & \\
\hline İfade28 & & & $-0,454$ & & \\
\hline İfade45 & & & $-0,428$ & & \\
\hline İfade36 & & & $-0,397$ & & \\
\hline İfade42 & & & & $-0,778$ & \\
\hline İfade44 & & & & $-0,685$ & \\
\hline İfade41 & & & & $-0,561$ & \\
\hline İfade40 & & & & $-0,475$ & \\
\hline İfade43 & & & & $-0,440$ & \\
\hline İfade39 & & & & $-0,406$ & \\
\hline
\end{tabular}


Aktaș, M. C., Karaman, E., Bölen, M. C.

DEÜ SBE Dergisi, Cilt: 23, Sayl: 2

\begin{tabular}{ll}
\hline Ifade24 & $-0,666$ \\
\hline İade30 & $-0,607$ \\
\hline İfade29 & $-0,495$ \\
\hline
\end{tabular}

Faktör analizleri sonucuna göre ifadeler; reklam, güven, deneyim, ürün ve tercih faktörleri olarak beş faktör altında toplanmaktadır.

Faktör yüklerinin anlamlı olarak kabul edilme durumu örneklem sayısına göre değişmektedir. Örneğin; 350 katılımcının olduğu bir örneklemde 0,3 üzeri yükler anlamlı kabul edilmektedir. Örneklem sayısı arttıç̧a anlamlı kabul edilebilecek yük değerleri düşmektedir. Negatif değerler ise mutlak değer olarak ele alınmalıdır (Yaşlığlu, 2017, s. 78). Bu kapsamda, Tablo 7'de yer alan yük değerlerinin de 402 katılımcı sayısı göz önünde bulundurularak uygun düzeyde olduğu kabul edilebilir.

\section{KATILIMCILARIN YAŞLARINA GÖRE SOSYAL TICARET İLGİLERİ}

"Katılımcıların sosyal ticarete karşı genel ilgileri ile yaşları arasında anlamlı bir farklılık var midır?" sorusuna cevap bulmak amaciyla yapılan ANOVA testi sonuçları Tablo 8'de paylaşılmıştır.

Tablo 7: Katılımcıların Yaşlarına Göre Genel İlgileri İçin ANOVA Testi Sonucu

\begin{tabular}{llcccc}
\hline & $\begin{array}{l}\text { Kareler } \\
\text { Toplamı }\end{array}$ & SD & $\begin{array}{c}\text { Kareler } \\
\text { Ortalamas }\end{array}$ & F & Sig. \\
\hline Gruplar arası & 6,246 & 3 & 2,082 & 4,859 & 0,002 \\
Gruplar içi & 170,560 & 398 & 0,429 & & \\
\hline Toplam & 176,807 & 401 & & & \\
\hline
\end{tabular}

Tablo 8 incelendiğinde $\mathrm{p}$ değerinin 0,05 'ten küçük olması nedeniyle katılımcıların yaşları ve genel ilgileri arasında anlamlı bir farklılık olduğu görülmektedir. Bu farklılığın hangi yaş grupları arasında olduğunun belirlenebilmesi için Post Hoc testi gerçekleştirilmiş ve sonuçları Tablo 9'da paylaşılmıştır.

Tablo 8: Katılımcıların Yaşlarına Göre Genel İlgileri Post Hoc Testi

\begin{tabular}{|c|c|c|c|c|c|c|}
\hline \multicolumn{7}{|c|}{ Tukey HSD } \\
\hline \multirow{2}{*}{ (I) Yaş } & \multirow{2}{*}{ (J) Yaş } & \multirow{2}{*}{$\begin{array}{c}\text { Ortalama } \\
\text { Farkları (I-J) }\end{array}$} & \multirow{2}{*}{ Std. Hata } & \multirow{2}{*}{ Sig. } & \multicolumn{2}{|c|}{ 95\% Güven Aralığ } \\
\hline & & & & & Alt Sinır & Üst Sınır \\
\hline \multirow{3}{*}{25 Altı } & $25-34$ & 0,34028 & 0,19364 & 0,296 & $-0,1593$ & 0,8399 \\
\hline & $35-44$ & 0,44456 & 0,19726 & 0,111 & $-0,0643$ & 0,9535 \\
\hline & $45-54$ & $0,85354^{*}$ & 0,24999 & 0,004 & 0,2086 & 1,4985 \\
\hline \multirow{3}{*}{$25-34$} & 25 Altı & $-0,34028$ & 0,19364 & 0,296 & $-0,8399$ & 0,1593 \\
\hline & $35-44$ & 0,10428 & 0,07060 & 0,452 & $-0,0779$ & 0,2864 \\
\hline & $45-54$ & $0,51326^{*}$ & 0,16903 & 0,014 & 0,0772 & 0,9493 \\
\hline \multirow{3}{*}{$35-44$} & 25 Alt1 & $-0,44456$ & 0,19726 & 0,111 & $-0,9535$ & 0,0643 \\
\hline & $25-34$ & $-0,10428$ & 0,07060 & 0,452 & $-0,2864$ & 0,0779 \\
\hline & $45-54$ & 0,40898 & 0,17315 & 0,086 & $-0,0377$ & 0,8557 \\
\hline \multirow{3}{*}{$45-54$} & 25 Alt1 & $-0,85354^{*}$ & 0,24999 & 0,004 & $-1,4985$ & $-0,2086$ \\
\hline & $25-34$ & $-0,51326^{*}$ & 0,16903 & 0,014 & $-0,9493$ & $-0,0772$ \\
\hline & $35-44$ & $-0,40898$ & 0,17315 & 0,086 & $-0,8557$ & 0,0377 \\
\hline
\end{tabular}


Tablo 9 incelendiğinde 25 yaş altındaki katılımcılar ile 25-34 yaş aralığındaki katılımcıların genel ilgilerinin 45-54 yaş aralı̆̆ındaki katılımcılara göre daha yüksek olduğu görülmektedir $\left(\mathrm{F}_{(3-398)}=4.859\right.$, $\left.\mathrm{p}<0.05\right)$.

\section{Katılımeıların Yaşlarına Göre Reklam İlgileri}

"Katılımcıların sosyal ticarete karşı reklam ilgileri ile yaşları arasında anlamlı bir farklılık var mıdır?" sorusuna cevap bulmak amacıyla yapılan ANOVA testi sonuçları Tablo 10'da ifade edilmektedir.

Tablo 9: Katılımcıların Yaşlarına Göre Reklam İlgileri İçin ANOVA Testi Sonucu

\begin{tabular}{llcccc}
\hline & $\begin{array}{l}\text { Kareler } \\
\text { Toplamı }\end{array}$ & SD & $\begin{array}{c}\text { Kareler } \\
\text { Ortalaması }\end{array}$ & F & Sig. \\
\hline Gruplar arası & 12,701 & 3 & 4,234 & 5,230 & 0,001 \\
Gruplar içi & 322,147 & 398 & 0,809 & & \\
\hline Toplam & 334,848 & 401 & & & \\
\hline
\end{tabular}

Tablo 10 incelendiğinde $\mathrm{p}$ değerinin 0,05 'ten küçük olması nedeniyle katılımcıların yaşları ve reklam ilgileri arasında anlamlı bir farklılık olduğu görülmektedir. Bu farklılığın hangi yaş grupları arasında olduğunun belirlenebilmesi için Post Hoc testi gerçekleştirilmiş ve sonuçları Tablo 11'de paylaşılmıştır

Tablo 10: Katılımcıların Yaşlarına Göre Reklam İlgileri Post Hoc Testi

\begin{tabular}{llccccc}
\hline & \multicolumn{2}{c}{ Tukey HSD } & \multicolumn{2}{c}{ 95\% Güven Aralı̆̆ } \\
\hline \multirow{2}{*}{ (I) Yaş } & \multirow{2}{*}{ (J) Yaş } & $\begin{array}{c}\text { Ortalama } \\
\text { Farkları (I-J) }\end{array}$ & Std. Hata & Sig. & Alt Sınır & Üst Sınır \\
\cline { 6 - 7 } 25 Altı & $25-34$ & 0,66597 & 0,26613 & 0,061 & $-0,0206$ & 1,3526 \\
& $35-44$ & $0,85137^{*}$ & 0,27109 & 0,010 & 0,1520 & 1,5508 \\
& $45-54$ & $1,18750^{*}$ & 0,34357 & 0,003 & 0,3011 & 2,0739 \\
\hline \multirow{2}{*}{$25-34$} & 25 Altı & $-0,66597$ & 0,26613 & 0,061 & $-1,3526$ & 0,0206 \\
& $35-44$ & 0,18540 & 0,09702 & 0,225 & $-0,0649$ & 0,4357 \\
& $45-54$ & 0,52153 & 0,23230 & 0,113 & $-0,0778$ & 1,1208 \\
\hline \multirow{3}{*}{$35-44$} & 25 Altı & $-0,85137^{*}$ & 0,27109 & 0,010 & $-1,5508$ & $-0,1520$ \\
& $25-34$ & $-0,18540$ & 0,09702 & 0,225 & $-0,4357$ & 0,0649 \\
& $45-54$ & 0,33613 & 0,23797 & 0,492 & $-0,2778$ & 0,9501 \\
\hline \multirow{3}{*}{$45-54$} & 25 Altı & $-1,18750^{*}$ & 0,34357 & 0,003 & $-2,0739$ & $-0,3011$ \\
& $25-34$ & $-0,52153$ & 0,23230 & 0,113 & $-1,1208$ & 0,0778 \\
& $35-44$ & $-0,33613$ & 0,23797 & 0,492 & $-0,9501$ & 0,2778 \\
\hline
\end{tabular}

Tablo 11 incelendiğinde 25 yaş altındaki katılımcıların sosyal ticarette reklamlara bağlı ilgilerinin 35-44 yaş aralığındaki katılımcılar ile 45-54 yaş aralığındaki katılımcılara göre daha yüksek olduğu görülmektedir $\left(\mathrm{F}_{(3-398)}=5.230\right.$, $\mathrm{p}<0.05)$. 


\section{Katılımcıların Yaşlarına Göre Güven İlgileri}

"Katılımcıların sosyal ticarete karşı güven ilgileri ile yaşları arasında anlamlı bir farklılık var midır?" sorusuna cevap bulmak amaciyla yapılan ANOVA testi sonuçları Tablo 12'de ifade edilmektedir.

Tablo 11: Katılımcıların Yaşlarına Göre Güven İlgileri İçin ANOVA Testi Sonucu

\begin{tabular}{llcccc}
\hline & $\begin{array}{l}\text { Kareler } \\
\text { Toplamı }\end{array}$ & SD & $\begin{array}{c}\text { Kareler } \\
\text { Ortalaması }\end{array}$ & F & Sig. \\
\hline Gruplar arası & 2,420 & 3 & 0,807 & 1,141 & 0,332 \\
Gruplar içi & 281,267 & 398 & 0,707 & & \\
\hline Toplam & 283,687 & 401 & & & \\
\hline
\end{tabular}

Tablo 12 üzerinde yer alan verilerde, katılımcıların yaşları ve güven ilgileri arasındaki ilişki incelendiğinde $\mathrm{p}$ değerinin 0,05 'ten büyük olması nedeniyle anlamlı bir farklılık olmadığ görülmektedir $\left(\mathrm{F}_{(3-398)}=1.141, \mathrm{p}>0.05\right)$.

\section{Katılımcıların Yaşlarına Göre Deneyim İlgileri}

"Katılımcıların sosyal ticarete karşı deneyim ilgileri ile yaşları arasında anlamlı bir farklılık var mıdır?" sorusuna cevap bulmak amaciyla yapılan ANOVA testi sonuçları Tablo 13'te ifade edilmektedir.

Tablo 12: Katılımcıların Yaşlarına Göre Deneyim İlgileri İçin ANOVA

Testi Sonucu

\begin{tabular}{llcccc}
\hline & $\begin{array}{l}\text { Kareler } \\
\text { Toplamı }\end{array}$ & SD & $\begin{array}{c}\text { Kareler } \\
\text { Ortalamas }\end{array}$ & F & Sig. \\
\hline Gruplar arası & 7,999 & 3 & 2,666 & 4,848 & 0,003 \\
Gruplar içi & 218,906 & 398 & 0,550 & & \\
\hline Toplam & 226,906 & 401 & & & \\
\hline
\end{tabular}

Tablo 13 incelendiğinde, $\mathrm{p}$ değerinin 0,05 'ten küçük olması nedeniyle katılımcıların yaşları ve deneyim ilgileri arasında anlamlı bir farklılık olduğu görülmektedir. Bu farklılığın hangi yaş grupları arasında olduğunun belirlenebilmesi için Post Hoc testi gerçekleştirilmiş ve sonuçları Tablo 14'te paylaşı1mıştır.

Tablo 13: Katılımcıların Yaşlarına Göre Deneyim İlgileri Post Hoc Testi

\begin{tabular}{|c|c|c|c|c|c|c|}
\hline \multicolumn{7}{|c|}{ Tukey HSD } \\
\hline \multirow{2}{*}{ (I) Yaş } & \multirow{2}{*}{ (J) Yaş } & \multirow{2}{*}{$\begin{array}{c}\text { Ortalama } \\
\text { Farkları (I-J) }\end{array}$} & \multirow{2}{*}{ Std. Hata } & \multirow{2}{*}{ Sig. } & \multicolumn{2}{|c|}{ 95\% Güven Aralığ } \\
\hline & & & & & Alt Sinır & Üst Sınır \\
\hline \multirow{3}{*}{25 Altı } & $25-34$ & 0,47344 & 0,21938 & 0,137 & $-0,0925$ & 1,0394 \\
\hline & $35-44$ & 0,55706 & 0,22347 & 0,063 & $-0,0195$ & 1,1336 \\
\hline & $45-54$ & $1,02604^{*}$ & 0,28321 & 0,002 & 0,2954 & 1,7567 \\
\hline \multirow{3}{*}{$25-34$} & 25 Alt1 & $-0,47344$ & 0,21938 & 0,137 & $-1,0394$ & 0,0925 \\
\hline & $35-44$ & 0,08362 & 0,07998 & 0,723 & $-0,1227$ & 0,2900 \\
\hline & $45-54$ & $0,55260^{*}$ & 0,19149 & 0,021 & 0,0586 & 1,0466 \\
\hline \multirow{2}{*}{$35-44$} & 25 Alt1 & $-0,55706$ & 0,22347 & 0,063 & $-1,1336$ & 0,0195 \\
\hline & $25-34$ & $-0,08362$ & 0,07998 & 0,723 & $-0,2900$ & 0,1227 \\
\hline
\end{tabular}




\begin{tabular}{clccccc}
\hline & $45-54$ & 0,46898 & 0,19616 & 0,080 & $-0,0371$ & 0,9751 \\
\hline \multirow{3}{*}{$45-54$} & 25 Alt1 & $-1,02604^{*}$ & 0,28321 & 0,002 & $-1,7567$ & $-0,2954$ \\
& $25-34$ & $-0,55260^{*}$ & 0,19149 & 0,021 & $-1,0466$ & $-0,0586$ \\
& $35-44$ & $-0,46898$ & 0,19616 & 0,080 & $-0,9751$ & 0,0371 \\
\hline
\end{tabular}

Tablo 14 incelendiğinde 25 yaş altındaki katılımcılar ile 25-34 yaş aralığındaki katılımcıların sosyal ticarette deneyime bağlı ilgilerinin $45-54$ yaş aralığındaki katılımcılara göre yüksek olduğu görülmektedir $\left(\mathrm{F}_{(3-398)}=4.848\right.$, $\mathrm{p}<0.05)$.

\section{Katılımcıların Yaşlarına Göre Ürün İlgileri}

"Katılımcıların sosyal ticarete karşı ürün ilgileri ile yaşları arasında anlamlı bir farklılık var mıdır?" sorusuna cevap bulmak amacıyla yapılan ANOVA testi sonuçları Tablo 15'te ifade edilmektedir.

Tablo 14: Katılımcıların Yaşlarına Göre Ürün İlgileri İçin ANOVA Testi Sonucu

\begin{tabular}{llcccc}
\hline & $\begin{array}{l}\text { Kareler } \\
\text { Toplamı }\end{array}$ & SD & $\begin{array}{c}\text { Kareler } \\
\text { Ortalamas }\end{array}$ & F & Sig. \\
\hline Gruplar arası & 8,553 & 3 & 2,851 & 4,587 & 0,004 \\
Gruplar içi & 247,347 & 398 & 0,621 & & \\
\hline Toplam & 255,899 & 401 & & & \\
\hline
\end{tabular}

Tablo 15 incelendiğinde, $\mathrm{p}$ değerinin 0,05 'ten küçük olması nedeniyle katılımcıların yaşları ve ürün ilgileri arasında anlamlı bir farklılık olduğu görülmektedir. Bu farklılığın hangi yaş grupları arasında olduğunun belirlenebilmesi için Post Hoc testi gerçekleştirilmiş ve sonuçları Tablo 16'da paylaşılmıştır.

Tablo 15: Katılımcıların Yaşlarına Göre Ürün İlgileri Post Hoc Testi

\begin{tabular}{|c|c|c|c|c|c|c|}
\hline \multicolumn{7}{|c|}{ Tukey HSD } \\
\hline \multirow{2}{*}{ (I) Yaş } & \multirow{2}{*}{ (J) Yaş } & \multirow{2}{*}{$\begin{array}{c}\text { Ortalama } \\
\text { Farkları (I-J) }\end{array}$} & \multirow{2}{*}{ Std. Hata } & \multirow{2}{*}{ Sig. } & \multicolumn{2}{|c|}{ 95\% Güven Aralığı } \\
\hline & & & & & Alt Sinır & Üst Sınır \\
\hline \multirow{3}{*}{25 Alt1 } & $25-34$ & 0,37083 & 0,23319 & 0,385 & $-0,2308$ & 0,9725 \\
\hline & $35-44$ & 0,52260 & 0,23754 & 0,125 & $-0,0902$ & 1,1354 \\
\hline & $45-54$ & $0,95139^{*}$ & 0,30105 & 0,009 & 0,1747 & 1,7281 \\
\hline \multirow{3}{*}{$25-34$} & 25 Altı & $-0,37083$ & 0,23319 & 0,385 & $-0,9725$ & 0,2308 \\
\hline & $35-44$ & 0,15176 & 0,08501 & 0,282 & $-0,0676$ & 0,3711 \\
\hline & $45-54$ & $0,58056^{*}$ & 0,20355 & 0,024 & 0,0554 & 1,1057 \\
\hline \multirow{3}{*}{$35-44$} & 25 Altı & $-0,52260$ & 0,23754 & 0,125 & $-1,1354$ & 0,0902 \\
\hline & $25-34$ & $-0,15176$ & 0,08501 & 0,282 & $-0,3711$ & 0,0676 \\
\hline & $45-54$ & 0,42879 & 0,20852 & 0,169 & $-0,1092$ & 0,9668 \\
\hline \multirow{3}{*}{$45-54$} & 25 Alt1 & $-0,95139^{*}$ & 0,30105 & 0,009 & $-1,7281$ & $-0,1747$ \\
\hline & $25-34$ & $-0,58056^{*}$ & 0,20355 & 0,024 & $-1,1057$ & $-0,0554$ \\
\hline & $35-44$ & $-0,42879$ & 0,20852 & 0,169 & $-0,9668$ & 0,1092 \\
\hline
\end{tabular}

Tablo 16 incelendiğinde 25 yaş altındaki katılımcılar ile 25-34 yaş aralığındaki katılımcıların sosyal ticarette ürüne bağlı ilgilerinin 45-54 yaş 
Aktaș, M. C., Karaman, E., Bölen, M. C. DEÜ SBE Dergisi, Cilt: 23, Sayl: 2

aralığındaki katılımcılara göre yüksek olduğu görülmektedir $\left(\mathrm{F}_{(3-398)}=4.587\right.$, $\mathrm{p}<0.05)$.

\section{Katılımcıların Yaşlarına Göre Tercih İlgileri}

"Katılımcıların sosyal ticarete karşı tercih ilgileri ile yaşları arasında anlamlı bir farklılık var midır?" sorusuna cevap bulmak amaciyla yapılan ANOVA testi sonuçları Tablo 17'de ifade edilmektedir.

Tablo 16: Katılımcıların Yaşlarına Göre Tercih İlgileri İçin ANOVA Testi Sonucu

\begin{tabular}{llcccc}
\hline & $\begin{array}{l}\text { Kareler } \\
\text { Toplamı }\end{array}$ & SD & $\begin{array}{c}\text { Kareler } \\
\text { Ortalaması }\end{array}$ & F & Sig. \\
\hline Gruplar arası & 14,118 & 3 & 4,706 & 4,302 & 0,005 \\
Gruplar içi & 435,382 & 398 & 1,094 & & \\
\hline Toplam & 449,501 & 401 & & & \\
\hline
\end{tabular}

Tablo 17 incelendiğinde, $\mathrm{p}$ değerinin 0,05 'ten küçük olması nedeniyle katılımcıların yaşları ve tercih ilgileri arasında anlamlı bir farklılık olduğu görülmektedir. Bu farklılığın hangi yaş grupları arasında olduğunun belirlenebilmesi için Post Hoc testi gerçekleştirilmiş ve sonuçları Tablo 18'de paylaşılmıştır.

Tablo 17: Katılımcıların Yaşlarına Göre Tercih İlgileri Post Hoc Testi

\begin{tabular}{|c|c|c|c|c|c|c|}
\hline \multicolumn{7}{|c|}{ Tukey HSD } \\
\hline \multirow{2}{*}{ (I) Yaş } & \multirow{2}{*}{ (J) Yaş } & \multirow{2}{*}{$\begin{array}{c}\text { Ortalama } \\
\text { Farkları (I-J) }\end{array}$} & \multirow{2}{*}{ Std. Hata } & \multirow{2}{*}{ Sig. } & \multicolumn{2}{|c|}{ 95\% Güven Aralığı } \\
\hline & & & & & Alt Sinır & Üst Sınır \\
\hline \multirow{3}{*}{25 Altı } & $25-34$ & 0,67361 & 0,30938 & 0,131 & $-0,1246$ & 1,4718 \\
\hline & $35-44$ & $0,83706^{*}$ & 0,31516 & 0,041 & 0,0240 & 1,6501 \\
\hline & $45-54$ & $1,31250^{*}$ & 0,39941 & 0,006 & 0,2820 & 2,3430 \\
\hline \multirow{3}{*}{$25-34$} & 25 Alt1 & $-0,67361$ & 0,30938 & 0,131 & $-1,4718$ & 0,1246 \\
\hline & $35-44$ & 0,16345 & 0,11279 & 0,469 & $-0,1275$ & 0,4544 \\
\hline & $45-54$ & 0,63889 & 0,27005 & 0,085 & $-0,0578$ & 1,3356 \\
\hline \multirow{3}{*}{$35-44$} & 25 Alt1 & $-0,83706^{*}$ & 0,31516 & 0,041 & $-1,6501$ & $-0,0240$ \\
\hline & $25-34$ & $-0,16345$ & 0,11279 & 0,469 & $-0,4544$ & 0,1275 \\
\hline & $45-54$ & 0,47544 & 0,27665 & 0,315 & $-0,2383$ & 1,1892 \\
\hline \multirow{3}{*}{$45-54$} & 25 Alt1 & $-1,31250^{*}$ & 0,39941 & 0,006 & $-2,3430$ & $-0,2820$ \\
\hline & $25-34$ & $-0,63889$ & 0,27005 & 0,085 & $-1,3356$ & 0,0578 \\
\hline & $35-44$ & $-0,47544$ & 0,27665 & 0,315 & $-1,1892$ & 0,2383 \\
\hline
\end{tabular}

Tablo 18 incelendiğinde 25 yaş altındaki katılımcıların sosyal ticarette tercihe bağlı ilgilerinin 35-44 yaş aralığındaki katılımcılar ile 45-54 yaş aralığındaki katılımcılara göre yüksek olduğu görülmektedir $\left(\mathrm{F}_{(3-398)}=4.302\right.$, $\left.\mathrm{p}<0.05\right)$. 


\section{KATILIMCILARIN CINSIYYETLERINE GÖRE SOSYAL TICARET ILGILERİ}

"Katılımcıların sosyal ticarete karşı genel ilgileri ile cinsiyetleri arasında anlamlı bir farklılık var mıdır?" sorusunun yanıtını bulmak için Bağımsız Örneklem T Testi uygulanacaktır.

Tablo 18: Katılımcıların Cinsiyetlerine Göre Genel İlgilerinde Bağımsız Örneklem T-Testi Sonucu

\begin{tabular}{lcccccc}
\hline & $\mathbf{N}$ & Ortalama & SS & t & sd & p \\
\hline Erkek & 198 & 2,7389 & 0,64232 & \multirow{2}{*}{7,519} & \multirow{2}{*}{400} & \multirow{2}{*}{0,000} \\
Kadın & 204 & 3,2057 & 0,60226 & & \\
\hline
\end{tabular}

Tablo 19'da yer alan verilere göre erkeklerin genel ilgi puanının 2,7389 ortalamaya sahip olduğu görülmektedir. Kadın katılımcıların ortalama genel ilgi puanının ise 3,2057'dir. Bağımsız örneklem t-testi sonucunda p değerinin 0,05'ten küçük olması nedeniyle katılımcıların cinsiyetlerine göre sosyal ticaret üzerine genel ilgileri bakımından anlamlı bir farklılık olduğu ifade edilebilir. Ayrıca kadın katılımcıların sosyal ticaret üzerine genel ilgilerinin erkek katılımcılara göre yüksek olduğu görülmektedir [ $\mathrm{t}(400)=-7.519, \mathrm{p}<0.05]$.

\section{Katılımcıların Cinsiyetlerine Göre Reklam İlgileri}

"Katılımcıların sosyal ticarete karşı reklam ilgileri ile cinsiyetleri arasında anlamlı bir farklılık var mıdır?" sorusunun yanıtını bulmak için Bağımsız Örneklem $\mathrm{T}$ Testi uygulanacaktır.

Tablo 19: Katılımcıların Cinsiyetlerine Göre Reklam İlgilerinde Bağımsız Örneklem T-Testi Sonucu

\begin{tabular}{lcccccc}
\hline & $\mathbf{N}$ & Ortalama & SS & t & Sd & P \\
\hline Erkek & 198 & 2,4714 & 0,91658 & \multirow{2}{*}{0,807} & \multirow{2}{*}{400} & 0,000 \\
Kadın & 204 & 2,9804 & 0,84022 & $-5,807$ & & \\
\hline
\end{tabular}

Tablo 20'de yer alan verilere göre erkeklerin reklam ilgi puanının 2,4714 ortalamaya sahip olduğu görülmektedir. Kadın katılımcıların ortalama reklam ilgi puanının ise 2,9804 olduğu görülmektedir. Bağımsız örneklem t-testi sonucunda $p$ değerinin 0,05 'ten küçük olması nedeniyle katılımcıların cinsiyetlerine göre sosyal ticarette reklama bağlı ilgileri bakımından anlamlı bir farklılık olduğu ifade edilebilir. Ayrıca kadın katılımcıların sosyal ticarette reklama bağlı ilgilerinin erkek katılımcılara göre yüksek olduğu görülmektedir [ $\mathrm{t}(400)=-5.807, \mathrm{p}<0.05]$.

\section{Katılımcıların Cinsiyetlerine Göre Güven İlgileri}

"Katılımcıların sosyal ticarete karşı güven ilgileri ile cinsiyetleri arasında anlamlı bir farklılık var mıdır?" sorusunun yanıtı için Bağımsız Örneklem T Testi uygulanacaktır. 
Tablo 20: Katılımcıların Cinsiyetlerine Göre Güven İlgilerinde Bağımsız Örneklem T-Testi Sonucu

\begin{tabular}{lcccccc}
\hline & $\mathbf{N}$ & Ortalama & SS & t & sd & p \\
\hline Erkek & 198 & 2,8146 & 0,80496 & \multirow{2}{*}{6,498} & \multirow{2}{*}{400} & \multirow{2}{*}{0,000} \\
Kadın & 204 & 3,3338 & 0,79703 & & & \\
\hline
\end{tabular}

Tablo 21'de yer alan verilere göre erkeklerin güven ilgi puanının 2,8146 ortalamaya sahip olduğu görülmektedir. Kadın katılımcıların ortalama güven ilgi puanının ise 3,3338 olduğu görülmektedir. Bağımsız örneklem t-testi sonucunda $p$ değerinin 0,05 'ten küçük olması nedeniyle katılımcıların cinsiyetlerine göre sosyal ticarette güvene bağlı ilgileri bakımından anlamlı bir farklılık olduğu ifade edilebilir. Ayrıca kadın katılımcıların sosyal ticarette güvene bağlı ilgilerinin erkek katılımcilara göre yüksek olduğu görülmektedir [ $[\mathrm{t}(400)=-6.498, \mathrm{p}<0.05]$.

\section{Katılımcıların Cinsiyetlerine Göre Deneyim İlgileri}

"Katılımcıların sosyal ticarete karşı deneyim ilgileri ile cinsiyetleri arasında anlamlı bir farklılık var mıdır?" sorusunun yanıtını bulmak için Bağımsız Örneklem T Testi uygulanacaktır.

Tablo 21: Katılımcıların Cinsiyetlerine Göre Deneyim İlgilerinde Bağımsız Örneklem T-Testi Sonucu

\begin{tabular}{|c|c|c|c|c|c|c|}
\hline & $\mathbf{N}$ & Ortalama & SS & $\mathbf{t}$ & sd & p \\
\hline Erkek & 198 & 3,0341 & 0,77175 & \multirow{2}{*}{$-5,941$} & \multirow{2}{*}{400} & \multirow{2}{*}{0,000} \\
\hline Kadın & 204 & 3,4620 & 0,67018 & & & \\
\hline
\end{tabular}

Tablo 22'de yer alan verilere göre erkeklerin deneyim ilgi puanlarının 3,0341 ortalamaya sahip olduğu görülmektedir. Kadın katılımcıların ortalama deneyim ilgi puanının ise 3,4620'dir. Bağımsız örneklem t-testi sonucunda $\mathrm{p}$ değerinin 0,05 'ten küçük olması nedeniyle katılımcıların cinsiyetlerine göre sosyal ticarette deneyime bağlı ilgileri bakımından anlamlı bir farklılık olduğu ifade edilebilir. Ayrıca kadın katılımcıların sosyal ticarette deneyime bağlı ilgilerinin erkek katılımcılara göre yüksek olduğu görülmektedir [ $\mathrm{t}(400)=-5.941, \mathrm{p}<0.05]$.

\section{Katılımcıların Cinsiyetlerine Göre Ürün İlgileri}

"Katılımcıların sosyal ticarete karşı ürün ilgileri ile cinsiyetleri arasında anlamlı bir farklılık var mıdır?" sorusunun yanıtını bulmak için Bağımsız Örneklem $\mathrm{T}$ Testi uygulanacaktır.

Tablo 22: Katılımcıların Cinsiyetlerine Göre Ürün İlgilerinde Bağımsız Örneklem T-Testi Sonucu

\begin{tabular}{lcccccc}
\hline & N & Ortalama & SS & t & sd & p \\
\hline Erkek & 198 & 2,4470 & 0,82294 & \multirow{2}{*}{$-3,342$} & \multirow{2}{*}{400} & \multirow{2}{*}{0,001} \\
Kadın & 204 & 2,7100 & 0,75441 & & \\
\hline
\end{tabular}


Tablo 23'te yer alan verilere göre erkeklerin ürün ilgi puanlarının 2,4470 ortalamaya sahip olduğu görülmektedir. Kadın katılımcıların ortalama ürün ilgi puanının ise 2,7100 olduğu görülmektedir. Bağımsız örneklem t-testi sonucunda $\mathrm{p}$ değerinin 0,05 'ten küçük olması nedeniyle katılımcıların cinsiyetlerine göre sosyal ticarette ürüne bağlı ilgileri bakımından anlamlı bir farklılık olduğu ifade edilebilir. Ayrıca kadın katılımcıların sosyal ticarette ürüne bağlı ilgilerinin erkek katılımcılara göre yüksek olduğu görülmektedir [ $\mathrm{t}(400)=-3.342, \mathrm{p}<0.05]$.

\section{Katılımcıların Cinsiyetlerine Göre Tercih İlgileri}

"Katılımcıların sosyal ticarete karşı tercih ilgileri ile cinsiyetleri arasında anlamlı bir farklılık var mıdır?" sorusunun yanıtını bulmak için Bağımsız Örneklem T Testi uygulanacaktır.

Tablo 23: Katılımcıların Cinsiyetlerine Göre Tercih İlgilerinde Bağımsız Örneklem T-Testi Sonucu

\begin{tabular}{lcccccc}
\hline & $\mathbf{N}$ & Ortalama & SS & t & sd & p \\
\hline Erkek & 198 & 2,8182 & 1,01791 & \multirow{2}{*}{$-7,234$} & \multirow{2}{*}{400} & 0,000 \\
Kadin & 204 & 3,5376 & 0,97601 & & \\
\hline
\end{tabular}

Tablo 24'te yer alan verilere göre erkeklerin tercih ilgi puanlarını 2,8182 ortalamaya sahip olduğu görülmektedir. Kadın katılımcıların ortalama tercih ilgi puanının ise 3,5376 olduğu görülmektedir. Bağımsız örneklem t-testi sonucunda $p$ değerinin 0,05 'ten küçük olması nedeniyle katılımcıların cinsiyetlerine göre sosyal ticarette tercihe bağlı ilgileri bakımından anlamlı bir farklılık olduğu ifade edilebilir. Kadın katılımcıların sosyal ticarette tercihe bağlı ilgilerinin erkek katılımcılara göre yüksek olduğu görülmektedir [ $\mathrm{t}(400)=-7.234, \mathrm{p}<0.05]$.

\section{KATILIMCI İLGILERINIIN YAŞ VE CINSIYYET ÖZELLIKLERINE GÖRE KARŞILAŞTIRILMASI}

Anket yanıtları demografik özelliklere göre incelenirken sosyal ticaret kapsamında; genel ilgi, reklamlara yönelik ilgi, güven açısından ilgi, deneyim açısından ilgi, ürüne göre ilgi ve tercih açısından katılımcıların ilgi puanlarının analizleri gerçekleştirilmiştir. Bu bölümde ise katılımcıların sosyal ticaret ilgileri yaş ve cinsiyet özelliklerine göre çapraz tablolar aracılığıyla karşılaştırılarak incelenecektir.

\section{Katılımcıların Genel İlgi Puanlarına Göre Çapraz Tablo İncelemeleri}

Katılımcıların yaş ve cinsiyet özelliklerine göre genel ilgi puanlarının karşılaş̧ırmaları Tablo 25'te gösterilmektedir. 
Aktaș, M. C., Karaman, E., Bölen, M. C. DEÜ SBE Dergisi, Cilt: 23, Sayl: 2

Tablo 24: Katılımcıların Genel İlgi Puanlarının Yaş ve Cinsiyet Özelliklerine Göre Karşılaştırmaları

\begin{tabular}{llccc}
\hline Yaş & Cinsiyet & Ortalama & Std. Sapma & N \\
\hline \multirow{3}{*}{25 Altı } & Erkek & 2,9091 & 0,65322 & 4 \\
& Kadın & 3,5871 & 0,72001 & 8 \\
& Total & 3,3611 & 0,74681 & 12 \\
\hline \multirow{2}{*}{$25-34$} & Erkek & 2,7284 & 0,62503 & 108 \\
& Kadın & 3,2601 & 0,58668 & 132 \\
& Total & 3,0208 & 0,65865 & 240 \\
\hline \multirow{3}{*}{$35-44$} & Erkek & 2,7673 & 0,67515 & 78 \\
& Kadin & 3,1245 & 0,52089 & 134 \\
\hline \multirow{3}{*}{$45-54$} & Total & 2,9166 & 0,63826 & 8 \\
& Erkek & 2,5189 & 0,59985 & 8 \\
\hline \multirow{2}{*}{ Total } & Kadin & 2,4962 & 0,75973 & 16 \\
& Total & 2,5076 & 0,66137 & 198 \\
\hline
\end{tabular}

Tablo 25'te yer alan değerler incelendiğinde yaş ve cinsiyet özelliklerine göre sosyal ticaret üzerine genel ilgi en yüksek puan ortalamasının $(3,5871) 25$ yaş altındaki kadın katılımcılara ait olduğu görülmektedir. Yaş ve cinsiyet özelliklerine göre sosyal ticaret üzerine genel ilgide en düşük puan ortalaması $(2,4962)$ ise 45-54 yaş aralı̆̆ındaki kadın katılımcılara ait durumdadır. Buna göre 25 yaş altındaki kadın katılımciların sosyal ticaret faaliyetlerine genel ilgilerinin yüksek; 45-54 yaş aralığındaki kadın katılımcıların ise düşük seviyede olduğu görülmektedir Katılımcıların yaş ve cinsiyet özellikleri birlikte değerlendirildiğinde genel ilgilerindeki bu farklılıklar, $\mathrm{p}$ değerinin 0,05 'ten büyük olması nedeniyle anlamlı değildir $(\mathrm{p}=0.211, \mathrm{p}>0.05)$.

\section{Katılımcıların Reklam İlgi Puanlarına Göre Çapraz Tablo İncelemeleri}

Katılımcıların yaş ve cinsiyet özelliklerine göre reklam ilgi puanlarının karşılaştırmaları Tablo 26' da gösterilmektedir.

Tablo 25: Katılımcıların Reklam İlgi Puanlarının Yaş ve Cinsiyet Özelliklerine Göre Karşılaştırmaları

\begin{tabular}{llccc}
\hline Yaş & Cinsiyet & Ortalama & Std. Sapma & $\mathbf{N}$ \\
\hline \multirow{3}{*}{25 Altı } & Erkek & 2,9583 & 1,32200 & 4 \\
& Kadın & 3,7083 & 0,80055 & 8 \\
& Total & 3,4583 & 1,01036 & 12 \\
\hline \multirow{2}{*}{$25-34$} & Erkek & 2,4985 & 0,94597 & 108 \\
& Kadın & 3,0328 & 0,81088 & 132 \\
& Total & 2,7924 & 0,91214 & 240 \\
\hline \multirow{3}{*}{$35-44$} & Erkek & 2,4081 & 0,87972 & 78 \\
& Kadın & 2,8839 & 0,79514 & 56 \\
\hline \multirow{3}{*}{$45-54$} & Total & 2,6070 & 0,87464 & 8 \\
& Erkek & 2,4792 & 0,71513 & 8 \\
\hline
\end{tabular}


DEU Journal of GSSS, Vol: 23, Issue: 2

\begin{tabular}{lllll}
\hline \multirow{3}{*}{ Total } & Erkek & 2,4714 & 0,91658 & 198 \\
& Kadin & 2,9804 & 0,84022 & 204 \\
& Total & 2,7297 & 0,91380 & 402 \\
\hline
\end{tabular}

Tablo 26'da yer alan değerler incelendiğinde yaş ve cinsiyet özelliklerine göre sosyal ticaret üzerine en yüksek reklam ilgi puanı ortalamasının $(3,7083) 25$ yaş altındaki kadın katılımcılara ait olduğu görülmektedir. Yaş ve cinsiyet özelliklerine göre sosyal ticaret üzerine en düşük reklam ilgi puanı ortalaması $(2,0625)$ ise 45-54 yaş aralı̆̆ındaki kadın katılımcılara ait durumdadır. Buna göre 25 yaş altındaki kadın katılımcıların sosyal ticaret faaliyetlerinde reklamlara bağl ilgilerinin yüksek; 45-54 yaş aralığındaki kadın katılımcıların ise düşük seviyede olduğu görülmektedir. Katılımcıların yaş ve cinsiyet özellikleri birlikte değerlendirildiğinde reklama bağlı ilgilerindeki bu farkl1lıklar, $\mathrm{p}$ değerinin 0,05 'ten büyük olması nedeniyle anlamlı değildir ( $\mathrm{p}=0.190, \mathrm{p}>0.05)$.

\section{Katılımcıların Güven İlgi Puanlarına Göre Çapraz Tablo İncelemeleri}

Katılımcıların yaş ve cinsiyet özelliklerine göre güven ilgi puanlarının karşı1laştırmaları Tablo 27'de gösterilmektedir.

Tablo 26: Katılımcıların Güven İlgi Puanlarının Yaş ve Cinsiyet Özelliklerine Göre Karşılaştırmaları

\begin{tabular}{llccc}
\hline Yaș & Cinsiyet & Ortalama & Std. Sapma & N \\
\hline \multirow{3}{*}{25 Altı } & Erkek & 2,6250 & 0,81394 & 4 \\
& Kadın & 3,2250 & 0,96177 & 8 \\
& Total & 3,0250 & 0,92552 & 12 \\
\hline \multirow{2}{*}{$25-34$} & Erkek & 2,7583 & 0,81724 & 132 \\
& Kadın & 3,3886 & 0,77869 & 240 \\
\hline \multirow{3}{*}{$35-44$} & Total & 3,1050 & 0,85446 & 78 \\
& Erkek & 2,9192 & 0,80519 & 56 \\
\hline \multirow{3}{*}{$45-54$} & Kadın & 3,3018 & 0,76002 & 134 \\
& Total & 3,0791 & 0,80628 & 8 \\
\hline \multirow{2}{*}{ Total } & Erkek & 2,6500 & 0,62335 & 8 \\
& Kadın & 2,7625 & 1,07695 & 16 \\
\hline
\end{tabular}

Tablo 27'de yer alan değerler incelendiğinde yaş ve cinsiyet özelliklerine göre sosyal ticaret üzerine en yüksek güven ilgi puanı ortalamasının $(3,3886)$ 25-34 yaş aralığındaki kadın katılımcılara ait olduğu görülmektedir. Yaş ve cinsiyet özelliklerine göre sosyal ticaret üzerine en düşük güven ilgi puanı ortalaması $(2,6250)$ ise 25 yaş altındaki erkek katılımcılara ait durumdadır. Buna göre 25-34 yaş aralığındaki kadın katılımcıların sosyal ticaret faaliyetlerinde güvene bağlı ilgilerinin yüksek; 25 yaş altındaki erkek katılımcıların ise düşük seviyede olduğu görülmektedir. Katılımcıların yaş ve cinsiyet özellikleri birlikte değerlendirildiğinde 
Aktaș, M. C., Karaman, E., Bölen, M. C.

DEÜ SBE Dergisi, Cilt: 23, Sayl: 2

güvene bağlı ilgilerindeki bu farkl1lıklar, $\mathrm{p}$ değerinin 0,05 'ten büyük olması nedeniyle anlamlı değildir ( $\mathrm{p}=0.370, \mathrm{p}>0.05)$.

\section{Katılımcıların Deneyim İlgi Puanlarına Göre Çapraz Tablo İncelemeleri}

Katılımcıların yaş ve cinsiyet özelliklerine göre deneyim ilgi puanlarının karşılaştırmaları Tablo 28'de gösterilmektedir.

Tablo 27: Katılımcıların Deneyim İlgi Puanlarının Yaş ve Cinsiyet Özelliklerine Göre Karşılaştırmaları

\begin{tabular}{llccc}
\hline Yaș & Cinsiyet & Ortalama & Std. Sapma & N \\
\hline \multirow{3}{*}{25 Altı } & Erkek & 3,4375 & 0,63328 & 4 \\
& Kadın & 3,9219 & 0,67459 & 8 \\
& Total & 3,7604 & 0,67516 & 12 \\
\hline \multirow{2}{*}{$25-34$} & Erkek & 3,0000 & 0,71430 & 108 \\
& Kadın & 3,5218 & 0,65263 & 132 \\
& Total & 3,2870 & 0,72770 & 240 \\
\hline \multirow{3}{*}{$35-44$} & Erkek & 3,1010 & 0,85067 & 78 \\
& Kadın & 3,3460 & 0,65366 & 56 \\
\hline \multirow{3}{*}{$45-54$} & Total & 3,2034 & 0,78125 & 134 \\
& Erkek & 2,6406 & 0,70216 & 8 \\
\hline \multirow{2}{*}{ Total } & Kadın & 2,8281 & 0,60481 & 16 \\
& Total & 2,7344 & 0,64043 & 198 \\
& Erkek & 3,0341 & 0,77175 & 204 \\
\hline
\end{tabular}

Tablo 28'de yer alan değerler incelendiğinde yaş ve cinsiyet özelliklerine göre sosyal ticaret üzerine en yüksek deneyim ilgi puanı ortalamasının $(3,9219) 25$ yaş altındaki kadın katılımcılara ait olduğu görülmektedir. Yaş ve cinsiyet özelliklerine göre sosyal ticaret üzerine en düşük deneyim ilgi puanı ortalaması $(2,6406)$ ise $45-54$ yaş aralığındaki erkek katılımcılara ait durumdadır. Buna göre 25 yaş altındaki kadın katılımcıların sosyal ticaret faaliyetlerinde deneyime bağlı ilgilerinin yüksek; 45-54 yaş aralığındaki erkek katılımcıların ise düşük seviyede olduğu görülmektedir. Katılımciların yaş ve cinsiyet özellikleri birlikte değerlendirildiğinde deneyime bağl1 ilgilerindeki bu farkl1lıklar, $p$ değerinin 0,05 'ten büyük olması nedeniyle anlamlı değildir ( $\mathrm{p}=0.307, \mathrm{p}>0.05)$.

\section{Katılımcıların Ürün İlgi Puanlarına Göre Çapraz Tablo İncelemeleri}

Katılımcıların yaş ve cinsiyet özelliklerine göre ürün ilgi puanlarının karşılaştırmaları Tablo 29' da gösterilmektedir.

Tablo 28: Katılımcıların Ürün İlgi Puanlarının Yaş ve Cinsiyet Özelliklerine Göre Karşılaştırmaları

\begin{tabular}{llccc}
\hline Yaş & Cinsiyet & Ortalama & Std. Sapma & N \\
\hline \multirow{2}{*}{25 Altı } & Erkek & 2,2917 & 0,59900 & 4 \\
& Kadın & 3,3750 & 0,71686 & 8 \\
& Total & 3,0139 & 0,84225 & 12 \\
\hline $25-34$ & Erkek & 2,4923 & 0,81947 & 108 \\
\hline
\end{tabular}


Bankacılık Sektörü Calıșanlarının...

DEU Journal of GSSS, Vol: 23, Issue: 2

\begin{tabular}{llccc}
\hline & Kadın & 2,7664 & 0,73989 & 132 \\
& Total & 2,6431 & 0,78701 & 240 \\
\hline \multirow{3}{*}{$35-44$} & Erkek & 2,4252 & 0,85011 & 78 \\
& Kadın & 2,5833 & 0,72683 & 56 \\
& Total & 2,4913 & 0,80187 & 134 \\
\hline \multirow{3}{*}{$45-54$} & Erkek & 2,1250 & 0,72237 & 8 \\
& Kadın & 2,0000 & 0,57044 & 16 \\
\hline \multirow{3}{*}{ Total } & Total & 2,0625 & 0,63209 & 198 \\
& Erkek & 2,4470 & 0,82294 & 204 \\
& Kadın & 2,7100 & 0,75441 & 402 \\
\hline
\end{tabular}

Tablo 29'da yer alan değerler incelendiğinde yaş ve cinsiyet özelliklerine göre sosyal ticaret üzerine en yüksek ürün ilgi puanı ortalamasının $(3,3750) 25$ yaş altındaki kadın katılımcılara ait olduğu görülmektedir. Yaş ve cinsiyet özelliklerine göre sosyal ticaret üzerine en düşük ürün ilgi puanı ortalaması $(2,0000)$ ise $45-54$ yaş aralığındaki kadın katılımcılara ait durumdadır. Buna göre 25 yaş altındaki kadın katılımcıların sosyal ticaret faaliyetlerinde ürüne bağlı ilgilerinin yüksek; 45-54 yaş aralığındaki kadın katılımcıların ise düşük seviyede olduğu görülmektedir. Katılımcıların yaş ve cinsiyet özellikleri birlikte değerlendirildiğinde ürüne bağlı ilgilerindeki bu farkl11ıklar, $\mathrm{p}$ değerinin 0,05 'ten büyük olması nedeniyle anlamlı değildir $(\mathrm{p}=0.216, \mathrm{p}>0.05)$.

\section{Katılımcıların Tercih İlgi Puanlarına Göre Çapraz Tablo İncelemeleri}

Katılımcıların yaş ve cinsiyet özelliklerine göre tercih ilgi puanlarının karşılaştırmaları Tablo 30'da gösterilmektedir.

Tablo 29: Katılımcıların Tercih İlgi Puanlarının Yaş ve Cinsiyet Özelliklerine Göre Karşılaştırmaları

\begin{tabular}{llccc}
\hline Yaş & Cinsiyet & Ortalama & Std. Sapma & $\mathbf{N}$ \\
\hline \multirow{3}{*}{25 Altı } & Erkek & 3,5833 & 1,03190 & 4 \\
& Kadın & 4,0833 & 0,75066 & 8 \\
& Total & 3,9167 & 0,84238 & 12 \\
\hline \multirow{3}{*}{$25-34$} & Erkek & 2,8364 & 1,05753 & 108 \\
& Kadın & 3,5758 & 0,92747 & 132 \\
& Total & 3,2431 & 1,05264 & 240 \\
\hline \multirow{3}{*}{$35-44$} & Erkek & 2,7735 & 0,97811 & 56 \\
& Kadın & 3,5060 & 1,02886 & 134 \\
\hline \multirow{3}{*}{$45-54$} & Total & 3,0796 & 1,05977 & 8 \\
& Erkek & 2,6250 & 0,82496 & 8 \\
\hline \multirow{2}{*}{ Total } & Kadın & 2,5833 & 1,10913 & 16 \\
& Total & 2,6042 & 0,94453 & 198 \\
& Erkek & 2,8182 & 1,01791 & 204 \\
\hline
\end{tabular}

Tablo 30'da yer alan değerler incelendiğinde yaş ve cinsiyet özelliklerine göre sosyal ticaret üzerine en yüksek tercih ilgi puanı ortalamasının $(4,0833) 25$ yaş altındaki kadın katılımcılara ait olduğu görülmektedir. Yaş ve cinsiyet özelliklerine 
göre sosyal ticaret üzerine en düşük tercih ilgi puanı ortalaması $(2,5833)$ ise $45-54$ yaş aralığındaki kadın katılımcılara ait durumdadır. Buna göre 25 yaş altındaki kadın katılımcıların sosyal ticaret faaliyetlerinde tercihe bağlı ilgilerinin yüksek; 45-54 yaş aralığındaki kadın katılımcıların ise düşük seviyede olduğu görülmektedir. Katılımcıların yaş ve cinsiyet özellikleri birlikte değerlendirildiğinde tercihe bağlı ilgilerindeki bu farkl11ıklar, $\mathrm{p}$ değerinin 0,05 'ten büyük olması nedeniyle anlamlı değildir $(\mathrm{p}=0.478, \mathrm{p}>0.05)$.

\section{SONUÇ VE TARTIŞMA}

$\mathrm{Bu}$ çalışmada bankacılık sektöründe çalışanların sosyal ticarete karşı ilgileri ölçülmüştür. Çalışma kapsamında uygulanan Bağımsız Örneklem T-Testi, ANOVA gibi testler doğrultusunda demografik özellikler ve ilgi puanları arasındaki farklılıklar hakkında değerli bulgular elde edilmiştir. Bu bulgular 1şığında çalışmada ulaşılan sonuçlar şu şekildedir:

Katılımcıların yaşlarına göre sosyal ticarete karşı ilgileri incelendiğinde sadece güven ilgilerinde farklılık bulunmadığı belirlenmiştir. Katılımcıların sosyal ticarete yönelik genel ilgi, deneyime bağlı ilgileri ve ürüne bağlı ilgileri açısından; 25 yaş altındaki katılımcılar ile 25-34 yaş aralığındaki katılımcıların ilgilerinin daha yüksek olduğu belirlenmiştir. Katılımcıların reklam ve tercihe bağlı ilgileri konusunda ise; 25 yaş altındaki katılımcıların ilgilerinin yüksek seviyede olduğu belirlenmiştir.

Katılımcıların cinsiyetlerine göre sosyal ticarete karşı ilgileri incelendiğinde genel ilgi dahil tüm ilgilerde farklılıklar bulunduğu belirlenmiştir. Katılımcıların genel ilgileri ile birlikte reklam, güven, deneyim, ürün ve tercihe bağlı ilgileri açısından; kadın katılımcıların ilgi düzeylerinin yüksek olduğu belirlenmiştir.

Çalışmada toplanan anket yanıtları için uygulanan analizlere ek olarak demografik özellikler arasında çapraz tablolar üzerinden de ilgi puanlarının karşılaştırmaları yapılmıştır. Katılımcıların yaşlarına göre yapılan incelemeler sonucunda; genç katılımcıların, diğer katılımcılara göre sosyal ticaret faaliyetlerine karşı ilgi düzeylerinin daha yüksek olduğu görülmüştür. Bu sonucu katılımcıların demografik özellikleri arasında yapılan çapraz tablo karşılaştırmalarındaki değerler de desteklemektedir. Tüm katılımcılara göre genç yaşlardaki kadın katılımcıların sosyal ticaret üzerine ilgilerinin diğer katılımcılara göre daha yüksek bir şekilde ön plana çıktığ1 görülmektedir; ancak tüm ilgi boyutlarına göre yaş ve cinsiyet özellikleri birlikte değerlendirildiğinde çapraz tablolardaki farklılıkların anlamlı olmadığ belirlenmiştir.

Yapılan diğer çalışmalar incelendiğinde; Özgiden (2013), çalışmasında yaptığ 1 araştırmalar sonucunda bir ürün veya hizmet hakkında satın alma şartı olmaksızın beğenme, paylaşma gibi eylemlerin gerçekleştirilebildiği sonucuna ulaşmıştır. Buna ek olarak, dijital ortamlar üzerinde bir ürün veya hizmet hakkında gerçekleştirilen eylemlerin cinsiyete göre farklılık göstermediği, sosyal medya 
platformları hakkındaki görüşler konusunda ise farklılıklar görüldüğ̈̈; ancak bu farklılı̆̆ın da düşük seviyede olduğu ifade edilmiştir. Bu çalışmada ise Özgiden (2013)'in çalışmasındaki cinsiyet özelliğiyle ilgili sonuçtan farklı olarak kadınların ilgilerinin daha yüksek olduğu sonucuna ulaşılmıştır.

Salvatori ve Marcantoni (2015) tarafindan hazırlanan çalışmada sosyal ticaret üzerine literatür incelemesi yapılmıştır ve çalışma sonucunda bu incelemenin sonuçları paylaşılmıştır. Araştırma sonuçlarına göre, özellikle 2010 - 2013 yılları arasında bu alana gösterilen ilgi artış göstermiştir. Bu çalışmada ise artış gösteren ilgilerin demografik özelliklere göre farklılıkları araştırılarak kadın katılımcıların sosyal ticarete ilgilerinin daha yüksek olduğu ve yaşa göre farkl1lıkların görüldüğü sonucuna ulaşılmıştır.

Durukal, Doğaner ve Armağan (2019) tarafindan yapılan çalışmada, eticaret faaliyetlerini kadınların daha fazla tercih edebildikleri ifade edilmiştir. $\mathrm{Bu}$ çalışmada da sosyal ticaret alanı için benzer sonuçlara ulaşılarak kadın katılımcıların erkek katılımcılara göre ilgilerinin daha yüksek olduğu belirlenmiştir.

Özeltürkay, Bozyiğit ve Gülmez (2017) tarafından yayınlanan çalışmada Instagram üzerinden alışveriş yapan tüketicilerin satın alma davranışları incelenmiştir. Araştırma sonucunda, Instagram üzerinde alışveriş yapan kullanıcıların büyük kısmını kadınlar oluşturmaktadır ve satın almayı tercih ettikleri ürünler, ağırlıklı olarak kıyafet, ayakkabı, takı ve saat gibi giyim/aksesuar kategorisindeki ürünlerden oluşmaktadır. Bu çalışmada da benzer şekilde; kadın katılımcıların, ürün ilgileri dahil olmak üzere sosyal ticaret ilgilerinin daha yüksek olduğu sonucuna ulaşılmıştır. Yaş özelliği açısından ise, 25 yaş altındaki katılımcılar ile 25-34 yaş aralığındaki katılımcıların ürüne bağlı ilgilerinin daha yüksek olduğu belirlenmiştir.

Söyleyici ve Bozkurt (2017) yılında yayınlanan çalışmasında sosyal medya platformlarının, kullanıcıların satın alma öncesi ve satın alma sonrasında davranışlar ile demografik özelliklere göre farklılık durumlarının belirlenmesi hedeflenmiştir. Analiz sonuçlarına göre sosyal medya platformlarının, satın alma öncesi ve satın alma sonrası davranışlar, yaş ve eğitim özellikleri açısından farklılık göstermektedir. $\mathrm{Bu}$ çalışmada ise, cinsiyet özelliği açısından da farklılıklar olduğu sonucuna ulaşılmış, kadın katılımcıların sosyal ticarete ilgilerinin daha yüksek olduğu belirlenmiştir.

Sarıer ve Zümrüt tarafından 2017 yılında yayınlanan çalışmada, kullanıcıların Instagram'da geçirdikleri süreye göre, reklamlardan etkilenme durumları araştırılmıştır. Çalışma sonuçlarına göre Instagram'da geçirilen süre bakımından; 2 saat ve üstü vakit geçiren kullanıcıların reklam içeriğine karşı duyarlı oldukları ve reklam içeriklerine önem verdikleri belirlenmiştir. Bu çalışmada ise, 25 yaş altındaki katılımcıların sosyal ticarette reklam ilgilerinin diğer katılımcılara göre daha yüksek olduğu belirlenmiştir. Ayrıca kadın katılımcıların sosyal ticarete ilgilerinin erkek katılımcılara göre yüksek olduğu sonucuna da ulaşılmıştır. 
Chen, Su ve Widjaja tarafından 2016 yılında yayınlanan çalışmada Facebook platformunu ticaret faaliyetleri için kullanan üyelerin alış ve satış grubu üzerindeki faaliyetlerinde reklam içerikleri ve beğeni sayılarının satın alma dürtüsüne etkileri araştırılmıştır. Araştırma sonucunda reklam metinlerinin ve beğeni sayılarının önemli faktörlerinin, üyeler açısından Facebook üzerinde alış ve satış grubunda satın alma dürtüsünü artırabileceği ifade edilmektedir. Bu çalışmada ise, kadın katılımcılar ile 25 yaş altındaki katılımcıların reklam ilgilerinin diğer katılımcılara göre daha yüksek olduğu sonucuna ulaşılmıştır.

Turgut (2016) çalışmasında, sosyal medya platformlarında bulunan reklamların tüketicilerin satın alma niyetleri üzerindeki etkilerini incelemiştir. Kavukçu (2018) çalışmasında, sosyal ağ platformlarında bulunan reklamların, tüketicilerin satın alma kararları konusunda etkiye sahip olup olmadığını incelemiştir. Ürgen (2019) de çalışmasında, sosyal medya platformlarında bulunan reklamların özellikle genç yaştaki tüketicilerin satın alma tarzlarında tutum, davranış ve satın alma niyetlerine olan etkilerini araştırmıştır. Turgut (2016), Kavukçu (2018) ve Ürgen (2019) tüketicilerin satın alma konusundaki kararlarında reklamların etkiye sahip olduğu sonucuna ulaşmıştır. Bu çalışmada ise, reklamlara yönelik ilgi noktasında; kadın katılımcılar ile 25 yaş altındaki katılımcıların ilgilerinin daha yüksek olduğu sonucuna ulaşılmıştır.

Katılımcılardan elde edilen bulgular dikkate alındığında bankacılık sektöründe çalışan diğer katılımcılara göre genç yaşlardaki kadın tüketicilerin sosyal ticaret faaliyetlerine yönelik ilgi düzeylerinin yüksek olduğu görülmüştür. Elde edilen bu bulgu, Durukal, Doğaner ve Armağan (2019) ile Özeltürkay, Bozyiğit ve Gülmez (2017) tarafından yapılan çalışmaların sonuçları ile tutarlıdır. Buna göre diğer demografik gruplara göre, genç kadın katılımcıların sosyal ticarete daha ilgilidirler. Önceki çalışmalar ile birlikte değerlendirildiğinde elde edilen bu sonuç, cinsiyet ve yaş özelliğinin sosyal ticaret için önemli olduğunu vurgulamaktadır. Buna göre sosyal ticaret faaliyetleri gerçekleştiren ve daha fazla tüketiciye ulaşmayı hedefleyen girişimciler veya işletmeler, yaş ve cinsiyet özelliklerini dikkate alarak pazarlama ve satış stratejilerini belirlemelidirler.

Yapılan bu çalışma ve karşılaştırılan diğer çalışmalar arasında benzer sonuçlar elde edilebildiği gibi, birbirinden farklı sonuçlar da elde edilmiştir. Örneğin Orun (2017), sosyal ticarette uygunluk riski algısında yaş, gelir durumu, medeni durum ve eğitim durumu özelliklerine göre anlamlı bir farklılık olduğunu belirlemiştir. Bu çalışmada ise medeni duruma göre bir farkl1lık belirlenmemiştir. Özgiden (2013), dijital ortamlar üzerinde bir ürün veya hizmet hakkında gerçekleştirilen eylemlerin cinsiyete göre farklılık göstermediği, sosyal medya platformları hakkındaki görüşler konusunda ise farklılık görüldüğü ancak bu farklılığın düşük seviyede olduğu ifade edilmiştir. Bu çalışmada ise Özgiden (2013)'in çalışmasındaki cinsiyet özelliğiyle ilgili sonuçtan farklı olarak kadınların ilgilerinin daha yüksek olduğu sonucuna ulaşılmıştır. Diğer çalışmalara göre bu çalışma ile genel bir karşılaştırma yapıldığında, çalışmanın örnekleminin bankacılık 
sektörü çalışanlarından oluşması ve bu sektörde çalışanların finansal okuryazarlıklarının yüksek olması (Ünal, Boz ve Ateşer, 2019, s. 112) nedeniyle bankacılık sektöründe çalışan personellerin görüş ve düşünceleri diğer kişilere göre farklılık göstermiş olabilir. Ayrıca çalışmaya katılanların önemli bir kısmının dijital teknolojinin içerisinde yetişen ve dijital okuryazarlığı diğer jenerasyonlara göre nispeten yüksek jenerasyonlardaki kişilerden oluşması (Prensky, 2001, ss. 1-3), sosyal ticaret konusundaki görüşlerini farklılaştıran bir unsur olabilir. Nitekim farklı kuşakların e-ticarete adaptasyonu ve e-ticareti kullanım şekilleri birbirinden farklı olduğu önceki çalışmalarda belirtilmiştir (Demirdöğmez ve Taş, 2020, s. 28)

Çalışmada sadece bankacılık sektöründe çalışanların yanıtları değerlendirmeye alınmıştır. Kullanıcılardan elde edilecek olan veriler sektörlere göre değişiklik gösterebilmektedir. Bu nedenle; eğitim, sağl1k, ticaret vb. sektörlerde çalışan kullanıcılara yönelik olarak kapsamlı ve detaylı bir araştırma yapılabilir. Yapılacak çalışmalardan elde edilecek sonuçlar sektörlere göre bu çalışmadaki sonuçlar ile karşılaştırılabilir.

Çalışma kapsamında, katılımcıların yoğun bir sektörde bulunmaları nedeniyle anket formunda görüş ve düşüncelerin ifade edilebileceği açık uçlu sorulara yer verilmemiştir. Bu doğrultuda, katılımcıların demografik özelliklere göre ilgilerindeki farklılıkların gerçek sebeplerinin belirlenmesi amacıyla açık uçlu sorulara yer verilen veya mülakat içeren nitel çalışmalar yapılabilir.

\section{KAYNAKÇA}

Akar, E. (2018). E-ticaret sosyal ticaret mobil ticaret pazarlama temelli yaklaşım. Ankara: Seçkin Yayıncılık.

Alican, C., \& Saban, A. (2013). Ortaokul ve lisede öğrenim gören öğrencilerin sosyal medya kullanımına ilişkin tutumları: Ürgüp örneği. Erciyes Üniversitesi Sosyal Bilimler Enstitüsü Dergisi, 1 (35), 1-14.

Chen, J. V., Su, B.-c., \& Widjaja, A. E. (2016). Facebook C2C social commerce: A study of online impulse buying. Decision Support Systems, 57-69.

Creswell, J. W. (2016). Araştırma deseni: Nitel, nicel ve karma yontem yaklaşımları. (Çev. Edt. Selcuk Besir Demir), Ankara: Egiten Kitap.

Demirdöğmez, M., \& Taş, H. Y. (2020). z kuşağının E-ticaret algısı ve Eticareti kullanma sıklığı. Turan: Stratejik Araştırmalar Merkezi, 12(46), 26-32.

Demirdöğmez, M., Gültekin, N., \& Taş, H. Y. (2018). Türkiye'de e-ticaret sektörünün yıllara göre gelişimi. OPUS Uluslararası Toplum Araştırmaları Dergisi, 8(15), 2216-2236.

Durukal, E., Doğaner, M., \& Armağan, E. (2019). E-ticaret sitelerinde algılanan sosyal medya pazarlaması faaliyetlerinin e-sadakate etkisi. Işsetme Araştırmaları Dergisi, 11 (1), 129-143. 
Econsultancy (2019). The state of social Commerce in Southeast Asia https://info2.magento.com/The-State-of-Social-Commerce-in-Southeast-Asia.html (Erişim Tarihi: 2021).

Emir, O., \& Durmaz, G. (2009). Afyonkarahisar'ın termal turizm imaj1 üzerine bir değerlendirme. Anatolia Turizm Araştırmaları Dergisi, 20 (1), 25-32.

Erbay, Ş., \& Beydoğan, H. Ö. (2017). Eğitimcilerin eğitim araştırmalarına yönelik tutumları. Ahi Evran Üniversitesi Kırşehir Eğitim Fakültesi Dergisi, 18 (3), 246-260.

Gibreel, O. A. I., AlOtaibi, D. A., Jeon, S., \& Yoo, B. (2015). Will instabusiness be the electronic contemporary bazaar? An exploratory analysis on electronic commerce in Kuwait. Proceedings of the 17th International Conference on Electronic Commerce 2015, pp. 1-6.

Huang, Z., \& Benyoucef, M. (2013). From e-commerce to social commerce: A close look at design features. Electronic Commerce Research and Applications, 12(4), 246-259.

Jang, H., Ko, I., \& Kim, J. (2013). The effect of group-buy social commerce and coupon on satisfaction and continuance intention--focusing on the Expectation Confirmation Model (ECM). 46th Hawaii International Conference on System Sciences, pp. 2938-2948. IEEE.

Karacan, D. (2006). Müşteri-odakl marka denkliği ve marka denkliği unsurlarına yönelik tüketici tutumlarının ölçülmesi: Otel işletmeleri üzerine bir uygulama. (Yüksek Lisans Tezi). Çukurova Üniversitesi.

Kavukçu, M. (2018). Sosyal ăg sitelerindeki reklamların tüketicilerin satın alma davranışlarına etkisi. (Yüksek Lisans Tezi). Hitit Üniversitesi, Çorum.

Kemp (2020). Digital 2020 April Global Statshot https://wearesocial.com/blog/2020/04/digital-around-the-world-in-april-2020, (Erişim Tarihi: 2021).

Küçükgöncü, N. (2018). Sosyal medya reklamlarında tüketici algılarının tutum, davranış ve satın alma üzerindeki etkisi Kayseri'de bir uygulama. (Yüksek Lisans Tezi). Nuh Naci Yazgan Üniversitesi.

Liang, T.-P., \& Turban, E. (2011). Introduction to the special issue social commerce: A research framework for social commerce. International Journal of Electronic Commerce, ss. 5-13.

Onurlubaş, E., \& Öztürk, D. (2018). Sosyal medya uygulamalarının Y kuşağı satın alma davranışı üzerine etkisi: Instagram örneği. Uluslararası Toplum Araştırmaları Dergisi, 9 (16), ss. 986-1016. 
Orun, A. (2017). Elektronik ticaret ve sosyal ticaret ortamlarından alışveriş yapan tüketicilerin risk algisı. (Yüksek Lisans Tezi). Marmara Üniversitesi, İstanbul.

Örün, Ö., Orhan, D., Dönmez, P., \& Kurt, A. A. (2015). Öğretmen adaylarının bireysel yenilikçilik profilleri ve teknoloji tutum düzeyleri arasındaki ilişkinin incelenmesi. Trakya Üniversitesi Eğitim Fakültesi Dergisi, 5 (1), 65-76.

Özeltürkay, E. Y., Bozyiğit, S., \& Gülmez, M. (2017). Instagram'dan alışveriş yapan tüketicilerin satın alma davranışları: Keşifsel bir çalışma. Marmara Üniversitesi Öneri Dergisi, 12 (48), 175-198.

Özgiden, H. (2013). Dijital kültür sürecinde elektronik ticaretin dönüşümü: Sosyal ticaret uygulamaları. (Yüksek Lisans Tezi). Ege Üniversitesi, İzmir.

Ünal, S., Dursun, B. O. Z., \& Ataşer, A. (2019). Bireysel emeklilik sistemi üyeliği ve bazı demografik değişkenlerin finansal okuryazarlık ile ilişkisi. Sosyal Bilimler Metinleri, 2019(2), 104-115.

Prenksy, M. (2001). Digital natives, digital immigrants. On the Horizon, 9 (5), 1-6.

Rad, A. A., \& Benyoucef, M. (2010). A model for understanding social commerce. Conference on information systems applied research. Nashville.

Salvatori, L., \& Marcantoni, F. (2015). Social commerce: A literature review. Science and Information Conference, (ss. 257-262). London.

Sarıer, N., \& Zümrüt, S. (2017). Instagramda farklı süre geçiren kullanıcılar, Instagram reklamlarından farklı $\mathrm{m} 1$ etkilenir? Girişimcilik İnovasyon ve Pazarlama Araştırmaları Dergisi, 1 (1), ss. 1-19.

Söyleyici, G. T., \& Bozkurt, Ö. Ç. (2017). Sosyal medya ve tüketici davranışları ilişkisi: Türkiye'deki sosyal medya kullanıcıları üzerine bir araştırma. Kesit Akademi Dergisi, (9), 36-54.

Turgut, E. (2016). Sosyal medya reklamlarında tüketici algılamaları ile satın alma niyeti ve ăgızdan ă̆ıza iletişim arasındaki ilişsk. (Yüksek Lisans Tezi). Selçuk Üniversitesi, Konya.

Ürgen, S. (2019). Satın alma tarzları ve sosyal medya reklamlarına yönelik tutumlar: Genç tüketiciler üzerine bir araştırma. (Yüksek Lisans Tezi). Selçuk Üniversitesi, Konya.

Ying, M. (2012). Sosyal medya platformlar üzerinden pazarlama ve bu mecrayı etkin kullanan sektörler. (Yüksek Lisans Tezi). Kadir Has Üniversitesi, İstanbul. 
Aktaș, M. C., Karaman, E., Bölen, M. C. $\quad$ DEÜ SBE Dergisi, Cilt: 23, Sayl: 2

Yüksel, E. (2010). İlköğretim II. kademe öğrencilerinin bilgisayar tutumları ve ögrrenme stilleri arasındaki ilişkinin belirlenmesi. (Yüksek Lisans Tezi). Bahçeşehir Üniversitesi.

Zhong, Y. (2012). Social Commerce: A new electronic commerce. Eleventh Wuhan International Conference on e-Business (ss. 164-169). Association for Information Systems AIS eLibrary. 